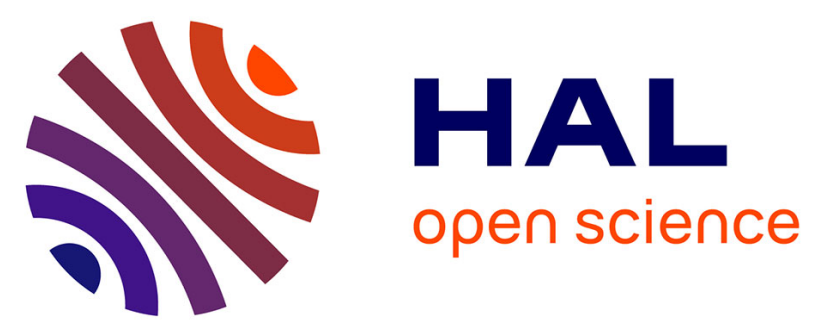

\title{
How to assess trace elements bioavailability for benthic organisms in lowly to moderately contaminated coastal sediments?
}

Sylvain Rigaud, Jean-Marie Garnier, Xavier Moreau, Laetitia De

Jong-Moreau, Nicolas Mayot, Perrine Chaurand, O. Radakovitch

\section{To cite this version:}

Sylvain Rigaud, Jean-Marie Garnier, Xavier Moreau, Laetitia De Jong-Moreau, Nicolas Mayot, et al.. How to assess trace elements bioavailability for benthic organisms in lowly to moderately contaminated coastal sediments?. Marine Pollution Bulletin, 2019, 140, pp.86 - 100. 10.1016/j.marpolbul.2019.01.007 . hal-01987918

\section{HAL Id: hal-01987918 https://hal.science/hal-01987918}

Submitted on 22 May 2019

HAL is a multi-disciplinary open access archive for the deposit and dissemination of scientific research documents, whether they are published or not. The documents may come from teaching and research institutions in France or abroad, or from public or private research centers.
L'archive ouverte pluridisciplinaire HAL, est destinée au dépôt et à la diffusion de documents scientifiques de niveau recherche, publiés ou non, émanant des établissements d'enseignement et de recherche français ou étrangers, des laboratoires publics ou privés.

\section{(ㅇ)(1) $\$$}

Distributed under a Creative Commons Attribution - NonCommercial - NoDerivatives 44.0 


\section{How to assess trace elements bioavailability for benthic organisms in lowly to moderately contaminated coastal sediments?}

Sylvain Rigaud ${ }^{1 *}$, Jean-Marie Garnier ${ }^{2}$, Xavier Moreau $^{3}$, Laetitia De Jong-Moreau ${ }^{3}$, Nicolas Mayot ${ }^{4}$, Perrine Chaurand ${ }^{2}$ and Olivier Radakovitch ${ }^{2,5}$

${ }^{1}$ Univ. Nîmes, EA 7352 CHROME, rue du Dr Georges Salan, F-30021 Nîmes, France.

${ }^{2}$ Aix Marseille Univ, CNRS, IRD, INRA, Coll France, CEREGE, Aix-en-Provence, France

${ }^{3}$ Aix Marseille Univ, Avignon Université, CNRS, IRD, IMBE, 3 place Victor Hugo 13331 Marseille, France

${ }^{4}$ GIPREB, Syndicat mixte Gestion Intégrée, Prospective et Restauration de l'Étang de Berre, Cours Mirabeau, 13130 Berre l'Étang, France.

${ }^{5}$ Institut de radioprotection et de sûreté nucléaire (IRSN), PSE-ENV/SRTE/LRTA, BP3, 13115 SaintPaul-Les-Durance, France

*Corresponding author: sylvain.rigaud@unimes.fr. Present address: Univ. Nîmes, EA 7352

CHROME, rue du Dr Georges Salan, 30021 Nîmes, France. 


\section{HIGHLIGHTS}

$>$ In lowly to moderately contaminated sediments bioaccumulation is not correlated with the bioavailable form of trace elements in sediment

$>$ Biological variabilities of the target organism, such as the polychaeta Alitta succinea, must be considered

$>$ Geochemical measurement of major elements in organism tissues may allow normalization procedures

$>$ Sediment contamination in the Berre lagoon is partly involved in the benthic ecosystem degradation

$>$ Such method cannot be applied for biologically regulated trace elements (i.e., Co and Zn in this study) 


\begin{abstract}
The bioavailibity of trace elements ( $\mathrm{As}, \mathrm{Cd}, \mathrm{Co}, \mathrm{Cr}, \mathrm{Cu}, \mathrm{Hg}, \mathrm{Ni}, \mathrm{Pb}, \mathrm{Zn}$ ) in lowly to moderately contaminated coastal sediments from the Berre lagoon, France, was assessed by comparing their potentially bioavailable concentrations and bioaccumulated concentrations in the polychaete Alitta succinea. No linear correlations were observed contrarily to what is generally observed in similar works in areas with highly contaminated sediment. Correlations between trace and major elements $(\mathrm{Fe}, \mathrm{Ca}, \mathrm{S}, \mathrm{Mg}, \mathrm{P}, \mathrm{Al})$ in Alitta succinea tissues and their distribution in organism tissues show that, in such lowly to moderately contaminated sediments, biological variabilities should be considered. Normalization procedures allow to take into account these variabilities and to identify that sediment contamination is partly involved in the benthic ecosystem degradation of the Berre lagoon. Alitta succinea cannot be used as relevant bioindicator for $\mathrm{Zn}$ and Co bioavailability in sediment, since these elements are regulated by this organism.
\end{abstract}

\title{
Keywords
}

Trace elements; Bioavailability; Sediment; Alitta succinea; Berre Lagoon. 


\section{Introduction}

Due to anthropogenic activities, many coastal areas present sediments contaminated by trace elements (TE) that can constitute a threat for aquatic ecosystems and human health. However, the link between contaminated sediments and potential adverse effects for aquatic ecosystems is not straightforward mainly due to the various physicochemical properties of sediment that influence the biological availability of TE (Tessier and Campbell, 1987). The knowledge of their bioavailability and mechanisms that control their transfer from sediment to biota is thus a primary issue in understanding the potential risks that contaminated sediments could constitute.

The bioavailability of TE in sediment is dependent on the geochemical properties of sediment (i.e. $\mathrm{pH}$, redox, grain size, contents of organic matter, clay, $\mathrm{Fe}, \mathrm{Mn}$ and $\mathrm{Al}$ oxy-hydroxides) that control their potential lability, but also on the biological properties of the target organism (i.e. physiology, feeding behavior, biological cycle, ecological functioning, life history) that control exposure routes and eventually regulation mechanisms of TE in tissues. Therefore, characterizing the bioavailability of TE in sediments implies to study the sediments and target benthic organisms both together.

These last decades, numerous works were carried out to assess the bioavailability of TE in sediments, generally by comparing the labile concentrations of $\mathrm{TE}$ in sediment with the corresponding bioaccumulated concentrations in benthic organism tissues (e.g., Luoma and Rainbow, 2008 for a review). The most commonly used techniques to assess the labile TE concentrations in sediment are single-step chemical extractions that "select" the labile fractions of TE, assumed to be potentially bioavailable, and "exclude" poorly labile elements (i.e. included in mineral crystalline structure), assumed to be non-bioavailable. Numerous protocols were developed using different reactants, such as acid solutions of $1 \mathrm{~N}$ or $0.5 \mathrm{~N} \mathrm{HCl}$ or $\mathrm{HNO}_{3}$, or ligand solution of EDTA. Obtained amounts are then compared to the total concentrations of TE in total organism or in specific tissues in order to discuss their effective bioavailability. Interestingly, the results reported often differ. For example, several studies reported significant positive correlations between the concentrations of TE in benthic organisms and those found in sediments and authors concluded on the efficiency of such approaches to transcript TE bioavailability in sediments (e.g. Bryan and Hummerston, 1977; Langston, 1980; Luoma and Bryan, 1982; Amiard et al., 2007; Hendozko et al., 2010). But sometimes normalization steps of TE contents in sediment with respect to the potential bearing phases (i.e., Fe and Mn oxydes, total 
organic carbon (TOC), acid volatile sulfide (AVS)) were necessary to improve the correlation (e.g. Luoma and Bryan, 1978; Langston, 1980; Langston, 1982; Di Toro et al., 1990; Luoma, 1989). Finally, in other cases, no correlation was found (e.g. Virgillio et al., 2003; Frangipane et al., 2005; Villares et al., 2005; Amiard et al., 2007). Both the absence of correlation and the need of normalization are explained by the lack of selectivity of the method: the reactants used also extract elements that are associated to non-bioavailable geochemical phases, like some crystalline, organic and/or sulfidic phases (Luoma, 1989; Di Toro et al., 1990). However, it is worth noting that the biological variabilities within the considered biological species (e.g. due to the variation in size, age and the sex of the collected samples of organisms) as well as the presence of regulation mechanisms, can impact the bioaccumulated concentrations of TE in organisms and thus may also explain the absence of positive linear correlation. Those biological features are generally not considered in geochemical approach due to the relatively difficulty to characterize precisely biological systems and to the need of a multidisciplinary approach with biologists. Furthermore, it must be noted that the linear correlations mentioned above were only observed in studies considering a very large range of TE contaminations of sediment, including extremely TE contaminated sediments. This indicates that the influences of those biological features may be neglected when considering highly contaminated sites. As most of coastal environments present lowly to moderately contaminated sediments, techniques to assess TE bioavailability for such coastal environments still need to be improved.

The Berre lagoon (southeast France) is an industrialized Mediterranean lagoon that was strongly polluted by TE and organic contaminants in the past decades and that is currently under rehabilitation (Jacquot et al., 1999; Accornero et al., 2008; Rigaud et al., 2011; Kanzari et al., 2012). The TE contamination in surface sediment is today low to moderate (Rigaud et al., 2011) but the benthic ecosystem is still strongly degraded. Since 1966, this benthic ecosystem has been also deeply degraded by the apparition of anoxic events and large salinity variations associated to freshwater releases from a hydroelectric power plant (Stora and Arnoux, 1983). The regulations adopted on these freshwater releases from 2005 have significantly reduced the salinity variations and the occurrence of anoxic events, but they did not lead to any clear improvements in the benthic ecosystem. These 
observations lead us to hypothesize that it could be partly related to the presence of contaminants in the sediments.

In this context, we collected sediment and organisms (the polychaete worm Alitta succinea) in the Berre lagoon in order to assess TE bioavailability in sediment. Typical biogeochemical approach, by comparing potentially bioavailable concentrations of TE in sediment obtained by chemical extractions with bioaccumulated TE concentrations in benthic organisms, was used. Then, we focused on data from chemical analysis of organisms and proposed a treatment to assess and overcome the influence of biological variabilities. To our knowledge, this approach, that corresponds to a common methodology used in geochemical characterization of sediment (e.g., Luoma and Rainbow, 2008), is applied here for the first time to a biological system and proved to be relevant to assess TE bioavailability in lowly to moderately contaminated coastal sediments.

\section{Material and methods}

\subsection{Sampling}

A total of 15 sites were sampled in the Berre lagoon (Figure 1): 4 in September 2008 (RN, VA, VC and $\mathrm{VN}$ ) and 11 in June 2010 (B1, B2, B3, B5, B7, B8, B9, B10, B11, B12 and B13). Five sites (VA, VC, VN, B10 and B11) are located in the Vaïne basin, the main industrialized part of the lagoon, while the others are located in coastal borders in the Central basin, outside the area subject to anoxia events in the water column (Figure 1). Note that the sites sampled in June 2010 also correspond to the stations selected by the management institute of the Berre lagoon (GIPREB) for benthic macrofauna monitoring.

Surface sediments were collected using a stainless steel sediment sampler (Orange peel grap sampler) in five replicates. Redox potential (Eh) and $\mathrm{pH}$ were immediately measured by inserting probe into fresh sediments. The surface layers of sediment $(0-3 \mathrm{~cm})$ for the solid phase analysis were scrapped using a plastic blade, pooled and placed in acid cleaned polyethylene containers and transported to the laboratory at $4^{\circ} \mathrm{C}$ in the dark. Sediment were freeze-dried at laboratory and sieved to $<63 \mu \mathrm{m}$ using nylon sieve. This fraction was chosen because it corresponds to that preferentially ingested by polychaetes (Dauer and Pardo, 2003) and because of its importance in the adsorption of the TE. 
The remaining sediment was sieved at $1 \mathrm{~mm}$ on field in order to recover Alitta succinea (Leuckart, 1847) (also previously called Neanthes succinea Frey and Leuckart, 1847 or Nereis succinea Leuckart, 1847 for examples) (Villalobos-Guerrero and Carrera-Parra, 2015). This polychaete worm was selected because it constitutes a major component of benthic biomass in the Berre lagoon and it is present throughout the year across the lagoon, except in anoxic areas. Besides the advantage of its abundance, the choice of this benthic organism is very appropriate since: (i) this deposit feeder lives in sediments and obtains its nutritional needs by sediment ingestion (Pardo and Dauer, 2003) and, thus TE remobilized during digestion constitute the main route of exposure (Wang and Fischer, 1999); (ii) polychaetes are a key species in estuarine and coastal benthic ecosystems, playing an important role in the structure and functioning of the benthic ecosystem (Hutchings, 1998); (iii) they constitute preys for many crustaceans, fish and waders (Scaps, 2002) and are therefore an important route of entry of trace elements in the food web (Rainbow et al., 2004; Rainbow et al. 2006; Coelho et al., 2008); (iv) it belongs to the class of Polychaeta often selected for studies on trace element bioaccumulation (e.g., Dean, 2008) and for which data are available in the literature. For each site, between 15 and 60 polychaetes (length $4.6 \pm 2.0 \mathrm{~cm}$ ) were collected, placed in polyethylene containers with clean synthetic seawater and transported to the laboratory at $4^{\circ} \mathrm{C}$. They were let in synthetic water (changed every day) during 3 days to allow the elimination of their gut contents. The purge efficiency was checked by visualization through the transparent body of the organisms and when it was not complete, the remaining sediment was extruded mechanically by slightly pressing the body with a stem acidwashed glass. Organisms were then washed with deionized water, freeze-dried, crushed and stored at $4^{\circ} \mathrm{C}$ until analysis.

\subsection{Analysis}

\subsubsection{Total Solid Phase Characterization}

An aliquot of freeze-dried sediment was totally digested in Teflon bomb in a microwave oven with ultrapure $\mathrm{HF}, \mathrm{HCl}$ and $\mathrm{HNO}_{3}$ mixture. After digestion, the acids were evaporated to near-dryness and the residues were recovered in $\mathrm{HNO}_{3} 2.5 \%$ and analyzed for $\mathrm{Ca}, \mathrm{Mg}, \mathrm{S}, \mathrm{P}, \mathrm{Al}, \mathrm{Fe}$ and Mn by ICP-AES (Ultima-C, Jobin Yvon, Horiba) and for As, $\mathrm{Cd}, \mathrm{Co}, \mathrm{Cr}, \mathrm{Cu}, \mathrm{Ni}, \mathrm{Pb}$ and $\mathrm{Zn}$ by ICP-MS (Thermo Scientific X Series II, Plateforme AETE-ISO - HydroSciences/OSU OREME, Montpellier - France). 
Elemental analyses were carried out using calibration solutions prepared with the same matrix as the samples $\left(\mathrm{HNO}_{3} 2.5 \%\right)$. Blank were always below $5 \%$ of contents in samples. Average analytical accuracies, estimated for total sediment digestion of reference sediments SGR-1, MAG-1 (USGS) and STSD-3 (CCRMP) and MAG-1 (USGS), were always below $5 \%$ for $\mathrm{Ca}, \mathrm{Mg}, \mathrm{S}, \mathrm{P}, \mathrm{Al}, \mathrm{Fe}, \mathrm{Mn}, \mathrm{As}$, $\mathrm{Cu}, \mathrm{Ni}, \mathrm{Pb}$ and $\mathrm{Zn}$ and around $10 \%$ for $\mathrm{Co}, \mathrm{Cd}$ and $\mathrm{Cr}$. Total $\mathrm{Hg}$ contents were obtained on dry sediment with a cold vapor atomic absorption spectrophotometer (AMA 254, Altec) according to the protocol described by Abi-Ghanem et al. (2011). Analytical accuracies were obtained using the reference sediment MESS-2 (NRCC) and were better than 3\%. Total organic carbon (TOC) and total inorganic carbon (TIC) contents were measured on a Leco 125 CS analyzer using the protocol described by Etcheber et al. (1999). Sediment grain size was measured using laser granulometer LS13320 (Beckman coulter), after elimination of organic matter in an oven at $450^{\circ} \mathrm{C}$ for $4 \mathrm{~h}$, and sample dispersion with defloculant $\left(\mathrm{NaPO}_{3}\right)_{6} 3 \%$. Sediment water content was determined from differences between fresh and freeze-dried sediment weight and porosity was assessed after correction for salt contents assuming a sediment density of 2.65. All measurements were done in duplicate and were corrected for salt contents.

\subsubsection{Chemical extractions procedures}

The potentially bioavailable fractions of TE in sediments were assessed by chemical extractions using two reactants: EDTA (all samples) and ascorbate (samples from June 2010 only). EDTA is an organic chelating agent supposed to extract elements adsorbed on mineral surface, included in carbonate phase and in the most reactive fractions of Fe and Mn oxy-hydroxides and organic matter (e.g., Agemian and Chau, 1976; Batley, 1987; Weimin et al., 1992; Tack and Verloo, 1996; Di Palma and Mecozzi, 2007). It was chosen because it is expected to be more selective than acid extraction, as shown for $\mathrm{Zn}, \mathrm{Cd}, \mathrm{Pb}$ and $\mathrm{Cu}$ in coastal sediments (McCready et al., 2003). Ascorbate reactant is a reductant commonly used to extract the most reactive forms of $\mathrm{Fe}$ and Mn oxy-hydroxides by reductive dissolution (Kostka and Luther, 1994; Anschutz et al., 1998) and trace metals or metalloids associated with these phases (e.g., Chaillou et al., 2003). It excludes elements associated to oxidizable phases such as organic matter and sulfides, expected to be non-bioavailable (Di toro et al., 1990, Luoma and Rainbow, 2008) and is therefore, expected to be also more selective than acid extraction. In addition, comparison of both 
extractants will allow us to gain information on TE speciation (i.e. main carrier phases) in sediment. Typically $500 \mathrm{mg}$ of freeze-dried sediment were dispersed into $30 \mathrm{ml}$ of EDTA (0.1 M adjusted to $\mathrm{pH}$ 8 using $\mathrm{NaOH})$ during 4 hours or into $30 \mathrm{ml}$ of ascorbate reactant $\left(50\right.$ g. $\mathrm{L}^{-1} \mathrm{NaHCO}_{3}, 50$ g.L $\mathrm{L}^{-1}$ sodium citrate and 20 g.L $\mathrm{L}^{-1}$ ascorbic acid, Kostka and Luther, 1994) during 24 hours. Reactants were recovered after 30 min decantation, filtered through $0.2 \mu \mathrm{m}$ cellulose acetate filter, 30 fold diluted in $\mathrm{HNO}_{3} 2.5 \%$ and stored at $4^{\circ} \mathrm{C}$. Solutions were analyzed for major (Ca, $\left.\mathrm{Mg}, \mathrm{Al}, \mathrm{Fe}, \mathrm{Mn}, \mathrm{P}, \mathrm{S}\right)$ and $\mathrm{TE}$ (As, $\mathrm{Cd}, \mathrm{Co}, \mathrm{Cr}, \mathrm{Cu}, \mathrm{Ni}, \mathrm{Pb}, \mathrm{Zn}$ ) by ICP-AES or ICP-MS following the same protocol described for total sediment and using calibration solutions prepared with the same matrix as the samples (EDTA or ascorbate). All extractions were carried out in duplicate and blank $(n=4)$ were done using the same protocol without sediment. Concentrations of major and TE in blank for ascorbate and EDTA extractant were lower than $5 \%$ of their concentrations in the samples for most of TE. However, contamination of EDTA extractants was found for $\mathrm{Cr}, \mathrm{Zn}$ and As (up to $20 \%$ of elements contents in samples) and for $\mathrm{Al}$ and $\mathrm{Ni}$ (up to $50 \%$ of elements contents in samples). Because blank values were quite reproducible $\left(\mathrm{Cr}: 0.21 \pm 0.01 \mathrm{ng} \cdot \mathrm{g}^{-1}\right.$; Ni: $1.67 \pm 0.04$ ng. $\mathrm{g}^{-1} ; \mathrm{Zn:} 3.75 \pm 0.18$ ng. $\mathrm{g}^{-1}$; As: $0.19 \pm$ 0.04 ng. $\mathrm{g}^{-1}$ and $\mathrm{Al}: 8.6 \pm 3.3 \mathrm{ng} \cdot \mathrm{g}^{-1}$ ), they were subtracted to sample contents. Contents of $\mathrm{Cu}$ and $\mathrm{Cd}$ in ascorbate extracts were very low and close to the values of blank $\left(0.36 \pm 0.02 \mathrm{ng} \cdot \mathrm{g}^{-1}\right.$ and $<0.01$ ng. $\mathrm{g}^{-1}$, respectively) indicating that they were not extracted by ascorbate. Concentrations of $\mathrm{S}, \mathrm{Mg}$ and $\mathrm{Ca}$ extracted by EDTA and ascorbate were corrected from contribution from porewaters taking into account their concentrations in porewaters (obtained from salinity and Dittmar's principle) and the porewater contents of sediments.

\subsubsection{Analysis of Alitta succinea}

About $350 \mathrm{mg}$ d.w. of organisms were digested in hot $\left(100^{\circ} \mathrm{C}\right)$ ultrapure concentrated $\mathrm{HNO}_{3}$ during 48h. Solutions were evaporated to near-dryness, recovered in $10 \mathrm{ml} \mathrm{HNO}_{3}(2.5 \%)$ and stored at $4^{\circ} \mathrm{C}$ until analysis. Major (Ca, Mg, $\mathrm{S}, \mathrm{P}, \mathrm{Al}, \mathrm{Fe}, \mathrm{Mn})$ and trace (As, $\mathrm{Cd}, \mathrm{Co}, \mathrm{Cr}, \mathrm{Cu}, \mathrm{Ni}, \mathrm{Pb}, \mathrm{Zn}$ ) elements were analyzed using the same protocol described for sediments. Total mercury content was determined on crushed worms using cold vapor atomic absorption spectrophotometer (AMA 254, Altec). 
Chemical mapping of paraffin-embedded non-purged organisms was performed by micro X-ray fluorescence spectroscopy $(\mu \mathrm{XRF})$. Measurements were carried out on a microscope $\left(\mathrm{XGT}^{5000}\right.$, Horiba Jobin Yvon) equipped with an X-ray source (Rh X-ray tube, accelerating voltage of $30 \mathrm{kV}$, current 1 $\mathrm{mA})$ producing a focused beam (100 $\mu \mathrm{m}$ spot size $)$ on the sample. X-ray emission from the irradiated sample was detected via an energy-dispersive X-ray spectrometer (EDX) equipped with a liquid nitrogen-cooled high-purity Si detector. An additional detector positioned below the sample collected the transmitted X-rays. Elements with atomic number $(\mathrm{Z})$ higher than $12(\mathrm{Mg})$ can be detected with detection limit depending on the nature of the probed matrix and ranging from few $\%$ mass for light elements to $100 \mu \mathrm{g} / \mathrm{g}$ for heavier elements. Elemental maps were recorded by scanning the selected regions of interest (256x256 pixels, pixel size of $24 \mu \mathrm{m})$, i.e. head and body of Alitta succinea with a total counting time of $8 \times 1000$ and $20 \times 1000$ s respectively. Note that as the incident X-ray beam penetrates through the sample, the obtained element maps are $2 \mathrm{D}$ projections of the $3 \mathrm{D}$ analyzed sample.

\section{Results}

\subsection{Sediment Characteristics}

The main physical and geochemical characteristics of sediments are reported in Table 1. The sediments are mainly carbonated $\left(38-57 \% \mathrm{CaCO}_{3}\right)$ and fine grained $(41-94 \%$ of $\mathrm{f}<63 \mu \mathrm{m})$. TOC contents vary between 1.8 and $4.0 \%$ with maximum values generally found in the Vaïne Basin. Sediments are reduced (-116 to $-214 \mathrm{mV})$ with neutral $\mathrm{pH}$ values (7.1-7.8).

The Vaïne Basin presents the highest sediment contamination by $\mathrm{Cd}, \mathrm{Cr}, \mathrm{Cu}, \mathrm{Hg}, \mathrm{Pb}$ and $\mathrm{Zn}$, reaching up to 10 times the natural geochemical background (NGB, obtained from deep sediment core samples, Giorgetti, 1981; Arnoux, 1987; Georgeaud, 1993; RNO, 1998) for $\mathrm{Cd}$ and $\mathrm{Pb}$ and between 3 and 4 for $\mathrm{Cu}, \mathrm{Hg}$ and $\mathrm{Zn}$ (Table 1 and examples of $\mathrm{Cd}, \mathrm{Hg}$ and $\mathrm{Pb}$ in Figure 2). The concentrations of these TE in the Central basin are significantly lower and close to, or slightly higher than, the NGB values $(<3$ times). Note however, two particularities in this distribution: (i) site B8 in the North of the Central basin shows the highest $\mathrm{Hg}$ concentrations measured in the lagoon (5.2 times the NGB; Figure 2); (ii) site VA in the south of the Vaïne basin shows concentrations similar to those of Central Basin for most TE. In contrast, there are no significant differences between both basins for $\mathrm{As}, \mathrm{Co}$ and $\mathrm{Ni}$, and 
their concentrations are close to the pre-industrial concentrations $(\leq 2$ times the NGB for As and Ni, Table 1).

Based on the TE enrichment factor (EF, i.e. ratio between TE that are contained in sediment and in the NGB) and according to the criteria proposed by Sutherland and Tolosa (2000), the sediment contamination in the Berre lagoon ranges from absent/low $(\mathrm{EF}<2)$ to moderate $(2<\mathrm{EF}<5)$, although punctually significant contamination $(5<\mathrm{EF}<20)$ can be encountered (i.e. $\mathrm{Cd}$ and $\mathrm{Pb}$ in sites $\mathrm{B} 10$ and B11, Table 1, Figure 2).

\subsection{Potentially bioavailable fractions and speciation of trace elements in sediments}

The TE concentrations extracted widely vary depending the extractant used and the sampling sites. In terms of lability, and thus potentially bioavailability, the highest extracted TE concentrations in the sediments were generally observed for $\mathrm{Cr}$ and $\mathrm{Zn}$ (EDTA and ascorbate) and $\mathrm{Cd}$ and $\mathrm{Pb}$ (EDTA) in the Vaïne Basin (see examples for $\mathrm{Cr}, \mathrm{Pb}$ and $\mathrm{Zn}$ in Figure 3, all data are reported in appendix $\mathrm{A} 1$ ). For $\mathrm{As}, \mathrm{Co}, \mathrm{Ni}$ and $\mathrm{Cu}$, no significant differences were observed between both basins.

The corresponding mean proportions of major and trace elements that are extracted in sediments by both extractants and the associated correlation coefficient $\left(r^{2}\right)$ between extracted contents by EDTA and ascorbate are reported in Table 2. In spite of geochemical differences between sediment characteristics, the proportion of extracted elements in sediment is relatively constant between sites for each extractant and this can be used to obtain information on speciation of trace elements in sediments of the Berre lagoon.

Whatever the extractant used, the labile fractions of $\mathrm{Ni}, \mathrm{Cr}$, As, Co and $\mathrm{Zn}$ are always $<30 \%$ of total concentrations in sediments. Moreover, good correlations $\left(0.62<\mathrm{r}^{2}<0.98\right)$ are observed between EDTA and ascorbate extractions for $\mathrm{Ni}, \mathrm{Cr}, \mathrm{As}, \mathrm{Co}$ and $\mathrm{Zn}$, meaning that these elements were probably extracted from the same labile pool by both extractants (Table 2). Their carrier phases may be Fe oxyhydroxydes and/or the sulfide phase since the extracted contents of $\mathrm{Fe}$ and $\mathrm{S}$ are also significantly correlated between both extractants $\left(r^{2}=0.74\right.$ and 0.90 , respectively) and are also in agreement with the early diagenesis of these elements in the Berre lagoon sediments (Rigaud et al., 2013).

On the other hand, no significant correlations were observed for $\mathrm{Pb}, \mathrm{Cu}$ and $\mathrm{Cd}\left(\mathrm{r}^{2}<0.18\right.$, Table 2) indicating that extractants target different labile pools for these TE. Actually, $\mathrm{Pb}, \mathrm{Cu}$ and $\mathrm{Cd}$ are 
significantly extracted by EDTA ( $66 \pm 12 \%, 38 \pm 10 \%$ and $32 \pm 13 \%$, respectively) but not, or very lowly, by ascorbate $(3 \pm 2 \%$ for $\mathrm{Pb}$ and under the quantification limit for $\mathrm{Cu}$ and $\mathrm{Cd}$; Table 2$)$. Since EDTA totally extracts the carbonate phases $(106 \pm 7 \%$ of $\mathrm{Ca}$, Table 2$)$ and also target the organic matter (Di Palma and Mecozzi, 2007), while it is not the case for ascorbate, we assumed that these elements were primarily associated to the carbonate phase or the organic matter. Previous results on TE lability, obtained from the same four samples of sediment collected in September 2008, demonstrated that $\mathrm{Pb}$ and $\mathrm{Cd}$ were strongly extracted by synthetic seawater adjusted to $\mathrm{pH} 4(74 \pm 2 \%$ and $57 \pm 11 \%$, respectively) while $\mathrm{Cu}$ was not $(3 \pm 1 \%$ ) (Rigaud et al., 2012). This denotes a likely association of $\mathrm{Pb}$ and $\mathrm{Cd}$ onto the carbonate phases $(85 \pm 7 \%$ of total $\mathrm{Ca}$ dissolved at $\mathrm{pH} 4)$ and an association of $\mathrm{Cu}$ with the organic matter, not extracted by acid reactant.

\subsection{Trace element contents in Alitta succinea}

The concentrations of trace and major elements in the tissues of Alitta succinea are strongly variables (Figure 4). For major elements, the relative standard deviation $(\mathrm{RSD}=$ standard deviation/average) range from $14 \%(\mathrm{P})$ to $70 \%(\mathrm{Al})$. For $\mathrm{Cd}, \mathrm{Cr}, \mathrm{Cu}, \mathrm{Hg}$ and $\mathrm{Pb}$, the RSD range between 55 and $100 \%$. Largest RSD values are observed when the concentrations in the tissues of organisms collected in few sites presented concentrations at least two times higher than in other sites (Figure 4): sites VA, VC and B11 for $\mathrm{Cd}$; site VC for $\mathrm{Cr}$ and $\mathrm{Cu}$; sites $\mathrm{VC}$ and $\mathrm{B} 8 \mathrm{for} \mathrm{Hg}$; sites VA and VC for Pb. Excepted the site B8 in the case of $\mathrm{Hg}$, all these sites are located in the Vaïne basin. In contrast, the RSD for As, Co, Ni and $\mathrm{Zn}$ are lower and range between 28 and $40 \%$. Theirs variabilities are however independent on the site locations since no significant differences can be observed between the sediments from the Vaïne basin and the Central basin (Figure 4).

TE concentrations in the tissues of Alitta succinea are not available in the literature. We therefore have compared the concentrations measured in this work with those reported for a very similar and widely studied polychaete, Hediste diversicolor (O.F. Müller, 1776) (Bryan and Hummerston, 1973; Bryan and Hummerston, 1977; Bryan et al., 1980; Langston et al., 1980; Luoma and Bryan, 1982; Bryan and Langston, 1992; Saiz-Salinas et al., 1996; Baeyens et al., 1997; Diez et al., 2000; Berthet et al., 2003; Virgilio et al., 2003; Frangipane et al., 2005; Villares et al., 2005; Amiard et al., 2007; Idardare et al., 
2008; Coelho et al., 2008; Solé et al., 2009). The concentration ranges measured in the Berre lagoon for most of the TE are close to the lower concentrations reported in the literature (Figure 4). The highest contents of $\mathrm{Cd}(\mathrm{VA}, \mathrm{VC}, \mathrm{B} 11), \mathrm{Cr}(\mathrm{VC}), \mathrm{Pb}$ (VA and $\mathrm{VC})$ and $\mathrm{Hg}$ (VC and $\mathrm{B} 8$ ) correspond to the values typically encountered in moderately to heavily contaminated coastal sites (Diez et al., 2000; Virgilio et al., 2002, Amiard et al., 2007; Idardare et al., 2008; Coelho et al., 2008). In contrast, Zn and Co behave differently since their concentrations are distributed throughout the range reported in the literature, from slightly to extremely contaminated sites (Bryan and Hummerston, 1973; Bryan et al. 1980; Diez et al., 2000; Amiard et al. 2007; Idardare et al., 2008).

Although less sensible than ICP-MS, the $\mu$ XRF technique provides spatially-resolved data, i.e. distribution and co-localization of elements in the various parts of the organism (integument, parapodia, jaws). The elements detected by $\mu \mathrm{XRF}$ in the Alitta tissues (head and body) are $\mathrm{Mg}, \mathrm{Al}, \mathrm{Si}$, $\mathrm{Ca}, \mathrm{K}, \mathrm{S}, \mathrm{P}, \mathrm{Fe}, \mathrm{Zn}$ and $\mathrm{Br}$ (Figure 5). P, S and $\mathrm{Ca}$ are mainly spread in parapodia and integument, in agreement with their role as essential constituents of biological matrix. K, Si and Fe are also detected in parapodia but at lower content. In the head, the jaws exhibit high content of $\mathrm{Br}$ and $\mathrm{Zn}$, as well as $\mathrm{Ca}$ and $\mathrm{Fe}$. Fe and $\mathrm{Ca}$ are also co-localized and strongly concentrated in the food bolus. Note that these organisms were not purged and the sediment inside the digestive tract can be visualized. The sediment is mainly rich in $\mathrm{Fe}$ and $\mathrm{S}$, and small amount of $\mathrm{Zn}, \mathrm{Ti}, \mathrm{Sr}, \mathrm{Mn}$ are also detected. Others TE are below the $\mu \mathrm{XRF}$ detection levels and so not detected.

\section{DISCUSSION}

\subsection{Assessment of sediment trace element bioavailability using traditional geochemical approach}

The representativeness of the labile concentrations of TE in sediments obtained by chemical extraction techniques, with respect to the bioavailable fraction for organisms, is generally assessed by comparing extracted concentrations with those bioaccumulated. A direct correlation between the labile pool concentrations of TE in sediments and the bioaccumulated ones relies on two assumptions: (1) the technique of extraction is directly representative or proportional to the concentration of bioavailable 
TE in sediments, and (2) the organisms bioaccumulate the TE proportionally to their bioavailable concentrations in sediment (no regulation, physiological variabilities or temporal variations).

Three cases are generally found in literature when the labile concentrations in sediments estimated by chemical extraction techniques and the concentrations accumulated by benthic organisms are compared. First, direct linear correlations are observed indicating that the two assumptions cited above are satisfied (Bryan and Hummerston, 1977; Luoma and Bryan, 1982; Bryan and Langston, 1992; Amiard et al., 2007). Second, linear correlations are observed when the extracted TE concentrations are normalized with respect to a potential carrier phase in sediment, such as Fe oxydes for As (Langston, 1980) or Pb (Luoma and Bryan, 1978), organic matter for Hg (Langston, 1982), AVS for Cd (Di Toro et al., 1990). In such case, the need for standardization reflects the low representativeness of the extractant for the bioavailable fraction (assumption 1 not satisfied) but the influence of biological factors for bioaccumulation of trace elements is negligible (assumption 2 satisfied). Third, there is no correlation (Villares et al. 2005; Frangipane et al., 2005, Amiard et al., 2007). In such cases, the factor responsible could be the low selectivity of the extractant and/or the role played by the organism in the assimilation of TE (hypotheses 1 and/or 2 not satisfied).

In this work, two interesting patterns can be highlighted from the comparison between the TE contents in Alitta succinea and in sediments. First, the highest $\mathrm{Hg}$ bioaccumulation in organisms is observed at the site presenting the highest total $\mathrm{Hg}$ concentration measured in sediments (Site B8, Figures 2 and 4). Second, the sites presenting the highest $\mathrm{Cd}, \mathrm{Cr}, \mathrm{Cu}$ and $\mathrm{Pb}$ concentrations in Alitta succinea are all located in the Vaine basin, which is also the area with the highest potentially bioavailable concentrations of these elements extracted by EDTA or ascorbate. This indicates that, in those sites, these TE are probably partly bioavailable. However, no direct linear correlation can be observed between the extracted TE concentrations in sediments and those accumulated in organisms when the whole study area is taken into account (Figure A1 in appendix). This is also the case when normalization procedure was carried out with the concentration of potentially bearing phases in the sediment such as Fe, TOC, S or Mn. These observations clearly position our results in the third case stated above: either the extraction technique used do not reflect the bioavailable fraction in sediment, and/or there are biological factors influencing the bioaccumulation. 
Two important differences exist between our work and those showing linear correlations. First, the scales of total and/or labile concentrations of TE in the sediments of these studies were very large, including poorly to extremely contaminated sites with a maximum/minimum ratio for labile trace element concentrations generally $>100$ (i.e., up to 350 for As and $\mathrm{Cu}$, Bryan and Langston, 1992). This ratio stays below 10 in our case. Second, the concentration ranges of TE in the studied polychaetes from the Berre lagoon correspond to concentrations several orders of magnitude lower than the maximum values reported in the cited above studies, except for $\mathrm{Co}$ and $\mathrm{Zn}$ (these specific cases will be discussed later). This tends to indicate that linear correlations between the concentrations of TE in sediments and organisms are only observed when very large ranges of sediment contaminations are studied, including highly-extremely contaminated sites. In such cases, the bioaccumulation is mainly controlled by the level of contamination, i.e. bioaccumulated concentrations are high because the labile concentrations are high. Factors influencing the geochemical speciation in sediments (e.g., nature of the carrier phase) play a secondary role (or can be taken into account by normalization methods) and biological factors are negligible. For sites with lower labile concentrations of TE in sediments, as in the Berre lagoon, the relationship between TE sediment and organisms concentrations is more complex and would also requires taking into account the biological factors controlling the bioaccumulation of TE in organisms. This cannot be considered when focusing only on the potential bioavailability of TE in sediments by chemical extractions and thus constitutes an important limit of this traditional method.

\subsection{Assessment of bioavailability of trace elements in sediment considering biological properties}

\subsubsection{Evidence for biological variabilities}

In the dataset collected during this study, two observations attest of biological variabilities between the organism samples. First, we observed large variations of the major element concentrations ( $\mathrm{Fe}, \mathrm{Ca}, \mathrm{P}$, $\mathrm{S}, \mathrm{Al}, \mathrm{Mg}$ ) in the organism tissues (Figure 4), while, for organisms of the same species therefore presenting similar biological characteristics, such concentrations are not expected to vary. Second, the bioaccumulated concentrations of $\mathrm{As}$, $\mathrm{Co}$ and $\mathrm{Ni}$ also present significant variations between sites despite the relative homogeneous distribution of their potentially bioavailable contents in sediments. Such physiological variabilities may be linked to variations of the size, age, seasonality and/or sex of 
the organisms. Although the precise identification of such biological factors are clearly beyond the objective of this study, the following sections will present a method to overcome these biological variabilities in order to assess bioavailability of TE in sediment.

\subsubsection{Assessment of the influence of biological variabilities on bioaccumulated trace element}

\section{concentrations}

The influence of the physiological variabilities on the element concentrations in organism tissues may be evaluated from the correlation matrix for the element concentrations in the organisms (Table 3, some correlations are also presented in Figure 6) and tentatively interpreted from the distribution of some elements observed by $\mu \mathrm{XRF}$ (Figure 5).

Concerning major elements, we observed significant correlations between $\mathrm{Fe}, \mathrm{Al}$, $\mathrm{Mn}$ and $\mathrm{Ca}\left(0.71<\mathrm{r}^{2}\right.$ $<0.76)$ and between $\mathrm{P}, \mathrm{Mg}$ and $\mathrm{S}\left(0.60<\mathrm{r}^{2}<0.85\right.$; Table 3$)$. We can thus conclude that $\mathrm{Al}$ and $\mathrm{Mn}$ are mainly located with $\mathrm{Fe}$ and $\mathrm{Ca}$ in the food bolus, the integument and in a part of jaws as it can be seen for $\mathrm{Fe}$ and $\mathrm{Ca}$ distribution from $\mu \mathrm{XRF}$ analysis, and that $\mathrm{Mg}$ is mainly spread in parapodia and integuments as it is the case for $\mathrm{P}$ and $\mathrm{S}$ (Figure 5). These major elements are necessary for the metabolism of living species and their variations of concentrations may be associated to the variation of the development state of the tissue/organ in the organisms. To our knowledge no studies report major element, such as $\mathrm{Ca}, \mathrm{Mg}, \mathrm{P}$ or $\mathrm{S}$ concentrations in polychaete tissues and very few studies report Fe and $\mathrm{Al}$ concentrations in addition to trace metals. When reported, it has been shown that the bioaccumulation of some major and trace elements can be dependent of biotic factors (development stage, age, sex...) and also regulated by biological mechanisms, such as metalloproteins for $\mathrm{Cd}, \mathrm{Zn}$ and Fe (Nejmeddine et al., 1988). For example, in Hediste diversicolor (O.F. Müller, 1776), a species belonging to the same sub-family as A. succinea (Nereidinae), the bioaccumulation of many elements (i.e. $\mathrm{Al} . \mathrm{Cd}, \mathrm{Cr}, \mathrm{Cu}, \mathrm{Hg}$. $\mathrm{Fe}, \mathrm{Mn}, \mathrm{Ni}, \mathrm{Pb}, \mathrm{Ti} . \mathrm{V}$ and $\mathrm{Zn}$ ) can vary considerably, according to abiotic factors (collection site, period of the year, temperature, salinity, cations studied) and to the age of the animals (Howard and Brown, 1983; Septier et al., 1991; Ozoh, 1994). Considering that the variability of major elements is a good indicator of the physiological variabilities in organism, looking at the correlation between trace and major elements in the Alitta tissues may give information about the influence of such biological variabilities on TE bioaccumulation. Two different patterns are observed. 
The first one is a significant positive correlation. This is the case for As with $\mathrm{S}\left(\mathrm{r}^{2}=0.91\right.$, Figure 6$)$ and in a lower extend with $\mathrm{P}$ and $\mathrm{Mg}\left(0.72<\mathrm{r}^{2}<0.79\right.$; Table 3$)$. Such correlation suggests that As is mainly accumulated in association with S-P-Mg in the parapodia and integuments. We must therefore assume that the variations of As concentrations in organism tissues can be only explained by the biological variabilities of organisms and consequently, that As is not strongly accumulated by Alitta succinea in the Berre lagoon, in agreement with its low labile concentrations in sediment. Although not as clear as for As, similar conclusion may be brought for Ni that also presents significant correlation $\left(0.60<\mathrm{r}^{2}<\right.$ 0.71) with $\mathrm{S}, \mathrm{Ca}$ and $\mathrm{Fe}$ (Table 3, the scatter plot for Ni with $\mathrm{S}$ is reported as example in Figure 6).

For the other TE, no high significant correlation can be detected (Table 3; the specific case of Co and Zn will be discussed next). However, the scatter plots between trace and major element concentrations in organism tissues also reveal that significant linear correlations exist if the sites presenting the highest trace/major element ratios in organisms are excluded (Figure 6). Here we excluded from the regression the organism samples from the station presenting the highest trace/major element ratios as many as the regression coefficient significantly increased. After such treatment, strong correlation was observed between $\mathrm{Cd}$ and $\mathrm{S}\left(\mathrm{r}^{2}=0.83\right.$, excluding sites $\left.\mathrm{VA}, \mathrm{VC}, \mathrm{B} 11, \mathrm{~B} 12, \mathrm{~B} 8\right)$, as well as for $\mathrm{Cr}$ $\left(\mathrm{r}^{2}=0.90\right.$, excluded sites $\mathrm{RN}, \mathrm{VA}, \mathrm{VC}, \mathrm{VN}$, and $\left.\mathrm{B} 10\right)$ and $\mathrm{Pb}\left(\mathrm{r}^{2}=0.82\right.$, excluding all sites from the Vaïne basin) with $\mathrm{Ca}$ (Figure 6). This indicates that for the sites included in the regression, the variation of the concentrations of $\mathrm{Cd}, \mathrm{Cr}$ and $\mathrm{Pb}$ in the organism tissues are mainly controlled by biological variabilities of the tissues where these elements are located (i.e., the integument and parapodia for $\mathrm{Cd}$, and the integument and a part of the jaws and the food bolus for $\mathrm{Cr}$ and $\mathrm{Pb}$ ). For excluded sites, these trace elements are present in excess relative to the distribution of their carrier tissues, which suggests a strong bioaccumulation and therefore the presence of an important pool of bioavailable trace elements in these sites. In the case of $\mathrm{Hg}$ and $\mathrm{Cu}$, no significant correlation was found with any major elements suggesting that their bioaccumulation is likely more complex.

The highest significant correlation $\left(r^{2}=0.93\right)$ is observed between Co and $\mathrm{Zn}$ (Table 3, Figure 6). It denotes a similar distribution of both elements in organism tissues, most probably in the tips of jaws as observed for Zn by $\mu$ XRF (Co was not detected by $\mu$ XRF, Figure 5). Accumulation of $\mathrm{Zn}$ as well as 
$\mathrm{Fe}, \mathrm{Ca}$ or $\mathrm{Br}$ in the jaws has been already reported in the literature for the genus Nereis. These elements are involved in the sclerotization of the jaws (Elfman et al., 1999; Lichtenegger et al., 2003; Broomell et al., 2006; Broomell et al., 2008). In Nereis sp., Zn concentrations in the jaws could reach up to 10\% in mass (Bryan and Gibbs, 1979; Lichtenegger et al., 2003; Elfman et al., 1999; Broomell et al., 2008; Rubin et al., 2010) and may constitute over $40 \%$ of total $\mathrm{Zn}$ mass of the organism (Bryan and Gibbs, 1979). Since the $\mathrm{Zn}$ and Co concentrations present strong variations among samples that cannot be attributed to changes in their labile concentrations in sediments, and given the high accumulation of $\mathrm{Zn}$ observed in the jaws, we propose that the variations in their concentrations are mainly associated with different states of sclerotization or with the size of the jaws in organisms from different sites. These two elements are thus regulated by assimilation and excretion processes in Alitta succinea. This could explain why the concentrations of these two elements in the organisms from the Berre lagoon are in the range of variations reported in the literature, from very lowly to extremely contaminated sites (Figure 4). Many studies have also reported the capacity of several polychaetes to regulate Zn (e.g., Bryan and Hummerston, 1973; Berthet et al., 2003, Amiard et al., 2007). Although such regulation has not been reported to date for Alitta succinea, our results suggest that regulation of $\mathrm{Zn}$ and $\mathrm{Co}$ is highly probable in this organism. Consequently, Alitta succinea cannot be used as bioindicator to assess the bioavailability of $\mathrm{Co}$ and $\mathrm{Zn}$ in sediment.

\subsubsection{Overcome of the biological variabilities by normalization procedure}

A method commonly used to suppress the influence of a variable in the distribution of another dependent variable is the normalization procedure. Such method is commonly used in sediment survey (e.g. Luoma and Rainbow, 2008). Here, we propose to transcript this method for its application on the TE concentrations in biological matrix in order to overcome the influence of the biological variabilities. For such approach, we have selected three TE that were found locally highly bioaccumulated in Alitta tissues: $\mathrm{Cd}, \mathrm{Cr}$ and $\mathrm{Pb}$. Comparison of their concentrations, normalized with respect to the representative elements of the tissues in which they could be accumulated in organisms $(\mathrm{Cd} / \mathrm{S}, \mathrm{Cr} / \mathrm{Ca}$ and $\mathrm{Pb} / \mathrm{Ca})$ with the labile concentrations obtained by EDTA and ascorbate extractants, shows that the fraction extracted by EDTA fits well the $\mathrm{Cd}$ and $\mathrm{Pb}$ bioavailability in sediment (Figure 7). However, none of these extractants reflects the bioavailability of $\mathrm{Cr}$ (results not shown). 


\subsection{Implication of sediment contamination on benthic ecosystem degradation}

The density and specific diversity of benthic macrofauna in sites sampled in June 2010 show that the lowest densities $\left(<1200\right.$ ind. $\left.\mathrm{m}^{-2}\right)$ and specific diversity ( $\leq 7$ species) are observed in sites B11, B10, B3 and B8 (GIPREB data, Figure 8). Sites B10 and B11 present the highest labile (EDTA and ascorbate) concentrations in sediment for most of the $\mathrm{TE}$ and the site $\mathrm{B} 8 \mathrm{has}$ the highest total $\mathrm{Hg}$ concentrations in sediments that were previously identified as bioavailable. Thus, the degraded state of benthic macrofauna in these sites is in good correspondence with the results obtained on the TE bioavailability in sediments and could be thus related to sediment contaminations. However, the role of organic contaminants in these sites should not be excluded.

The degradation observed in the site B3 is particular as it cannot be associated to contamination (low levels in TE and organic contaminants, Di Giorgio et al., 2011) but likely related to the proximity of the hydroelectric channel that release important amount of freshwater and suspended matter. Despite significant decrease of these freshwater amounts in recent years, it still has a very important local effect. Such local influence of physicochemical conditions on the degradation of the benthic macrofauna is also particularly visible at site B12, located at the mouth of the Caronte channel where the physicochemical variations are the lowest, and which has the highest specific diversity (Figure 8). Thus, although the presence of contaminants into the Vaïne basin or in the Gulf of Saint-Chamas could contribute to the degradation of benthic communities, in the rest of the Central basin, physicochemical factors appear to be the most important.

\section{CONCLUSION}

In this work, we show that, in a coastal area presenting lowly to moderately contaminated sediments, as in the Berre lagoon, the use of a bioindicator such as the polychaete worm Alitta succinea to assess the bioavailability of TE in sediment imply to consider the biological factors. Biological factors may induce the variation of concentration in TE in organism tissues over space and time, limiting the interpretation of sediment labile vs bioaccumulated TE relationships. From the correlation between major and trace element concentrations in organisms and the location of some of them in tissues by $\mu \mathrm{XRF}$, we were able to show that these factors could be related to physiological mechanisms such as 
sclerotization of the jaws. As such mechanism evolves with the development (age, sex and size of the worm), our results pointed out the need of a better assessment of biological mechanisms that control bioaccumulation for a better knowledge of major and trace element bioavailability in low to moderate contaminated sediments.

Through a normalization step of TE concentrations with respect to the concentration of a major element that can be representative of the main bearing tissues within the organisms, we were able to advance some hypotheses concerning the bioavailability of TE for benthic organisms in the Berre lagoon sediments. First, As, $\mathrm{Cu}$ and $\mathrm{Ni}$ do not seem to be highly bioaccumulated by Alitta succinea in relation to their low bioavailability in sediment. However, for $\mathrm{Cd}, \mathrm{Cr}, \mathrm{Hg}$ and $\mathrm{Pb}$, which showed higher bioavailability in sediment, uptake and bioaccumulation in organisms are important in some locations, the Vaïne basin $(\mathrm{Cd}, \mathrm{Cr}$ and $\mathrm{Pb})$ or in the Gulf of Saint-Chamas $(\mathrm{Hg})$, and could play a role in the degradation of the benthic ecosystem and cause a potential risk of contamination for the aquatic ecosystem of the lagoon. Also, we have shown that $\mathrm{Zn}$ and Co are mainly regulated by Alitta succinea for the sclerotization of the jaws and therefore, this organism cannot be used to assess their bioavailability in sediment.

Acknowledgements. We acknowledge for financial funding the Research Federation ECCOREV, the program INSU-CNRS EC2CO-BERTOX, the Région Provence-Alpes-Côtes-d'Azur and the GIPREB, 


\section{REFERENCES}

Abi-Ghanem, C, Nakhlé, K, Khalaf, G, Cossa, D. 2011. Mercury distribution and methylmercury mobility in the sediments of three sites on the Lebanese coast, Eastern Mediterranean. Arch. Environ. Contam. Toxicol. 60, 394-405.

Accornero, A, Gnerre, R, Manfra, L. 2008. Sediment concentrations of trace metals in the Berre lagoon (France): An assessment of contamination. Arch. Environ. Contam. Toxicol. 54, 372385.

Agemian, H, Chau, ASY. 1976. Evaluation of extraction techniques for the determination of metals in aquatic sediments. Analyst 101, 761-767.

Amiard, JC, Geffard, A, Amiard-Triquet, C, Crouzet, C. 2007. Relationship between the lability of sediment-bound metals $(\mathrm{Cd}, \mathrm{Cu}, \mathrm{Zn})$ and their bioaccumulation in benthic invertebrates. Estuar. Coast. Shelf Sci. 72, 511-521.

Anschutz, P, Zhong, S, Sundby, B, Mucci, A, Gobeil, C. 1998. Burial efficiency of phosphorus and the geochemistry of iron in continental margin sediments. Limnol. Oceanogr. 43, 53-64.

Arnoux, A, Roux, MR. 1987. Etude sédimentologique, minéralogique et géochimique de la carotte $n^{\circ} 3$ - Berre. Laboratoire d'hydrologie et de molysmologie aquatique, Université Aix-Marseille II, pp. 18.

Baeyens, W, Meuleman, C, Muhaya, B, Leermakers, M. 1997. Behaviour and speciation of mercury in the Scheldt estuary (water, sediments and benthic organisms). Hydrobiologia 366, 63-79.

Batley, G. 1987. Heavy metal speciation in waters, sediments and biota from Lake Macquarie, New South Wales. Aust. J. Mar. Fresh. Res. 38, 591-606.

Berthet, B, Mouneyrac, C, Amiard, JC, Amiard-Triquet, C, Berthelot, Y, Le Hen, A, Mastain, O, Rainbow, PS, Smith, BD. 2003. Accumulation and soluble binding of cadmium, copper, and zinc in the polychaete Hediste diversicolor from coastal sites with different trace metal bioavailabilities. Arch. Environ. Contam. Toxicol. 45, 468-478.

Broomell, CC, Mattoni, MA, Zok, FW, Waite, JH. 2006. Critical role of zinc in hardening of Nereis jaws. J. Exp. Biol. 209, 3219-3225.

Broomell, CC, Zok, FW, Waite, JH. 2008. Role of transition metals in sclerotization of biological tissue. Acta Biomater. 4, 2045-2051. 
Bryan, GW, Gibbs, PE. 1979. Zinc - a major inorganic component of nereid polychaete jaws. J. Mar. Biol. Assoc. UK 59, 969-973.

Bryan, GW, Hummerstone, LG. 1973. Adaptation of the polychaete Nereis diversicolor to estuarine sediments containing high concentrations of zinc and cadmium. J. Mar. Biol. Assoc. UK 53, 839-857.

Bryan, GW, Hummerstone, LG. 1977. Indicators of heavy-metals contamination in the Looe estuary (Cornwall) with particular regard to silver and lead. J. Mar. Biol. Assoc. UK 57, 75-92.

Bryan, GW, Langston, WJ. 1992. Bioavailability, accumulation and effects of heavy metals in sediments with special reference to United Kingdom estuaries: a review. Environ. Pollut. 76, 89-131.

Bryan, GW, Langston, WJ, Hummerstone, LG. 1980. The use of biological indicators of heavy metal contamination in estuaries. J. Mar. Biol. Assoc. UK 1, 73.

Chaillou, G, Schäfer, J, Anschutz, P, Lavaux, G, Blanc, G. 2003. The behaviour of arsenic in muddy sediments of the Bay of Biscay (France). Geochim. Cosmochim. Ac. 67, 2993-3003.

Coelho, JP, Nunes, M, Dolbeth, M, Pereira, ME, Duarte, AC, Pardal, MA. 2008. The role of two sediment-dwelling invertebrates on the mercury transfer from sediments to the estuarine trophic web. Estuar. Coast. Shelf Sci. 78, 505-512.

Dean, HK. 2008. The use of polychaetes (Annelida) as indicator species of marine pollution: a review Rev. Biol. Trop. 56, 11-38.

Di Giorgio, C, Malleret, L, Gueydon-Morin, C, Rigaud, S, De Méo, M. 2011. Comparison of two extraction procedures for the assessment of sediment genotoxicity: Implication of polar organic compounds. Mutat. Res.-Gen. Tox. En. 725, 1-12.

Di Palma, L, Mecozzi, R. 2007. Heavy metals mobilization from harbour sediments using EDTA and citric acid as chelating agents. J. Hazard. Mater. 147, 768-775.

Di Toro, DM, Mahony, JD, Hansen, DJ, Scott, KJ, Hicks, MB, Mayr, SM, Redmond, MS. 1990. Toxicity of cadmium in sediments: The role of acid volatile sulfide. Environ. Toxicol. Chem. 9, 1487-1502.

Díez, G, Soto, M, Cantón, L, Vaquero, MC, Marigómez, I. 2000. Hediste (Nereis) diversicolor as bioindicator of metal and organic chemical bioavailability: A field study. Ecotox. Env. Res. 3, 
$7-15$.

Elfman, M, Eriksson, M, Kristiansson, P, Malmqvist, K, Pallon, J. 1999. Application of microPIXE and STIM in analyses of fossil and recent polychaete jaws (scolecodonts). Nucl. Instrum. Meth. B 158, 287-291.

Etcheber, H, Relexans, J-C, Beliard, M, Weber, O, Buscail, R, Heussner, S. Distribution and quality of sedimentary organic matter on the Aquitanian margin (Bay of Biscay). Deep-Sea Res. II 46, 2249-2288.

Frangipane, G, Ghirardini, AV, Collavini, F, Zaggia, L, Pesce, A, Tagliapietra, D. 2005. Heavy metals in Hediste diversicolor (polychaeta: nereididae) and salt marsh sediments from the lagoon of Venice (Italy). Chem. Ecol. 21, 441 - 454.

Georgeaud, V, Rochette, P, Ambrosi, JP, Vandamme, D, Williamson, D. 1997. Relationship between heavy metals and magnetic properties in a large polluted catchment: the Etang de Berre (South of France). Phys. Chem. Earth 22, 211-214.

Giorgetti, C. 1981. Etude de l'état de pollution des sédiments de l'étang de Berre. 2ème partie: la pollution inorganique. $\mathrm{PhD}$ Thesis. Université de Marseille, pp. 132.

Hendozko, E, Szefer, P, Warzocha, J. 2010. Heavy metals in Macoma balthica and extractable metals in sediments from the southern Baltic Sea. Ecotox. Environ. Safe. 73, 152-163.

Howard, LS, Brown, BE. 1983. Natural variations in tissue concentration of copper, zinc and iron in the polychaete Nereis diversicolor, Mar. Biol. 78, 87-97.

Hutchings, P. 1998. Biodiversity and functioning of polychaetes in benthic sediments. Biodivers. Conserv. 7, 1133-1145.

Idardare, Z, Chiffoleau, JF, Moukrim, A, Alla, AA, Auger, D, Lefrere, L, Rozuel, E. 2008. Metal concentrations in sediment and Nereis diversicolor in two Moroccan lagoons: Khnifiss and Oualidia. Chem. Ecol. 24, 329-340.

Jacquot, F., Le Dréau, Y., Doumenq, P., Munoz, D., Guiliano, M., Imbert, G., \& Mille, G. 1999. The origins of hydrocarbons trapped in the lake of berre sediments. Chemosphere, 39, 1407-1419.

Kanzari, F., Syakti, A. D., Asia, L., Malleret, L., Mille, G., Jamoussi, B., Abderrabba M., Doumenq, P. 2012. Aliphatic hydrocarbons, polycyclic aromatic hydrocarbons, polychlorinated biphenyls, organochlorine, and organophosphorous pesticides in surface sediments from the 
Arc river and the Berre lagoon, France. Environ. Sci. Pollut. Res. 19, 559-576.

Kostka, JE, Luther Iii GW. 1994. Partitioning and speciation of solid phase iron in saltmarsh sediments. Geochim. Cosmochim. Ac. 58, 1701-1710.

Langston, WJ. 1980. Arsenic in U.K. estuarine sediments and its availability to benthic organisms. J. Mar. Biol. Assoc. UK 60, 869-881.

Langston, WJ. 1982. The Distribution of Mercury in British Estuarine Sediments and Its Availability to Deposit-Feeding Bivalves. J. Mar. Biol. Assoc. UK 62, 667-684.

Lichtenegger HC, Schoberl T, Ruokolainen JT, Cross JO, Heald SM, Birkedal H, et al. Zinc and mechanical prowess in the jaws of Nereis, a marine worm. Proceedings of the National Academy of Sciences of the United States of America 2003; 100: 9144-9149.

Luoma, SN. 1989. Can we determine the biological availability of sediment-bound trace elements? Hydrobiologia 176-177, 379-396.

Luoma, SN, Bryan, GW. 1978. Factors controlling the availability of sediment-bound lead to the estuarine bivalve Scrobicularia plana. J. Mar. Biol. Assoc. UK 58, 793-802.

Luoma, SN, Bryan GW. 1982. A statistical study of environmental factors controlling concentrations of heavy metals in the burrowing bivalve Scrobicularia plana and the polychaete Nereis diversicolor. Estuar. Coast. Shelf Sci. 15, 95-108.

Luoma, SN, Rainbow, PS. 2008. Metal contamination in aquatic environment. Science and lateral management. Cambridge University Press.

McCready, S, Birch, GF, Taylor, SE. 2003. Extraction of heavy metals in Sydney harbour sediments using $1 \mathrm{M} \mathrm{HCl}$ and $0.05 \mathrm{M}$ EDTA and implications for sediment-quality guidelines. Aust. J. Earth Sci. 50, 249-255.

Nejmeddine, A, Dhainaut-Courtois, N, Baert, JL, Sautière, P, Fournet, B, Boulenguer, PI. 1988. Purification and characterization of a cadmium-binding protein from Nereis diversicolor (Annelida Polychaeta). Comp. Biochem. Physiol. C. 89, 321-326.

Ozoh, PTE. 1994. The effect of salinity, temperature and time on the accumulation and depuration of copper in ragworm, Hediste (Nereis) diversicolor (o.f. Muller). Environ. Monit. Assess. 29, 155-166.

Pardo, EV, Dauer, DM. 2003. Particle size selection in individuals from epifaunal versus infaunal 
populations of the nereidid polychaete Neanthes succinea (Polychaeta: Nereididae). Hydrobiologia 496, 355-360.

Rainbow, PS, Geffard, A, Jeantet, AY, Smith, BD, Amiard, JC, Amiard-Triquet, C. 2004. Enhanced food-chain transfer of copper from a diet of copper-tolerant estuarine worms. Mar. Ecol.-Prog. Ser. 271, 183-191.

Rainbow, PS, Poirier, L, Smith, BD, Brix, KV, Luoma, SN. 2006. Trophic transfer of trace metals from the polychaete worm Nereis diversicolor to the polychaete $N$. virens and the decapod crustacean Palaemonetes varians. Mar. Ecol.-Prog. Ser. 321, 167-181.

Rigaud, S, Radakovitch, O, Nerini, D, Picon, P, Garnier, JM. 2011. Reconstructing historical trends of Berre lagoon contamination from surface sediment datasets: Influences of industrial regulations and anthropogenic silt inputs. J. Environ. Manage. 92, 2201-2210.

Rigaud, S, Di Giorgio, C, Radakovitch, O, Garnier, JM, De Méo, M. 2012. Genotoxicity of sediment extracts of the Berre lagoon (France). Chemosphere 88, 937-944.

Rigaud, S, Radakovitch, O, Couture, RM, Deflandre, B, Cossa, D, Garnier, C, Garnier, JM. 2013. Mobility and fluxes of trace elements and nutrients at the sediment-water interface of a lagoon under contrasting water column oxygenation conditions. Appl. Geochem. 31, 35-51.

RNO. 1998. Surveillance du milieu marin. Travaux du Réseau National d'Observation de la Qualité du Milieu Marin. Edition 1998. In: environnement I, editor. Ifremer.

Rubin, DJ, Miserez, A, Waite, JH, Jérôme, C, Stephen, JS. 2010. Diverse strategies of protein sclerotization in marine invertebrates: structure-property relationships in natural biomaterials. Adv. Insect Physiol. 38, 75-133.

Saiz-Salinas, JI, Ruiz, JM, Frances-Zubillaga, G. 1996. Heavy metal levels in intertidal sediments and biota from the bidasoa estuary. Mar. Pollut. Bull. 32, 69-71.

Scaps, P. 2002. A review of the biology, ecology and potential use of the common ragworm Hediste diversicolor (O.F. Müller) (Annelida: Polychaeta). Hydrobiologia 470, 203-218.

Septier, F, Demuynck, S, Thomas, P, Dhainaut-Courtois, N. 1991. Bioconcentration de métaux lourds chez une annélide polychète estuarienne : Nereis diversicolor. Oceanol. Acta, Proceedings of the International Congress on the environment of epicontinental seas. Lille. 20-22 March. $1990,11,263-274$. 
Solé, M, Kopecka-Pilarczyk, J, Blasco, JN. 2009. Pollution biomarkers in two estuarine invertebrates, Nereis diversicolor and Scrobicularia plana, from a Marsh ecosystem in SW Spain. Environ. Int. 35, 523-531.

Stora, G, Arnoux, A. 1986. Effect of large freshwater diversions on benthos of a mediterranean lagoon. Estuaries 6, 115-125.

Tack, FM, Verloo, MG. 1996. Impact of single reagent extraction using NH4OAc-EDTA on the solid phase distribution of metals in a contaminated dredged sediment. Sci. Tot. Environ. 178, 2936 .

Tessier, A, Campbell, PGC. 1987. Partitioning of trace metals in sediments: Relationships with bioavailability. Hydrobiologia 149, 43-52.

Villalobos-Guerrero, TF, Carrera-Parra, LF. 2015. Redescription of Alitta succinea (Leuckart, 1847) and reinstatement of A. acutifolia (Ehlers, 1901) n. comb. based upon morphological and molecular data (Polychaeta: Nereididae). Zootaxa 3919(1), 157-178.

Villares, R, Carral, E, Puente, XM, Carballeira, A. 2005. Metal Concentrations in Estuarine Invertebrates in Relation to Sediments. B. Environ. Contam. Tox. 75, 592-599.

Virgilio, M, Baroncini, N, Trombini, C, Abbiati, M. 2003. Relationships between sediments and tissue contamination and allozymic patterns in Hediste diversicolor (Polychaeta Nereididae) in the Pialassa lagoons (north Adriatic Sea). Oceanol. Acta 26, 85-92.

Wang, W-X, Fisher, NS. 1999. Delineating metal accumulation pathways for marine invertebrates. Sci. Tot. Environ. 237-238, 459-472.

Weimin, Y, Batley, GE, Ahsanullah, M. 1992. The ability of sediment extractants to measure the bioavailability of metals to three marine invertebrates. Sci. Tot. Environ. 125, 67-84. 


\section{TABLES}

Table 1: $\mathrm{pH}$, Eh (normalized to normal hydrogen electrode), percentage of particles $<63 \mu \mathrm{m}$, TOC, TIC (expressed as $\% \mathrm{CaCO}_{3}$ ) and total concentrations of major and trace elements in the fraction $<63 \mu \mathrm{m}$ of sediment ( \pm 1 standard deviation for two replicates). When available, the natural geochemical background (NGB, mean \pm 1 standard deviation) determined in the area from the deepest part of long sediment cores (Giorgetti, 1981; Arnoux, 1987; Georgeaud, 1993; RNO, 1998) is reported.

\begin{tabular}{|c|c|c|c|c|c|c|c|c|c|c|c|c|c|c|c|c|c|}
\hline Sites & $\begin{array}{l}\mathrm{pH} \\
\text { sed }\end{array}$ & $\begin{array}{c}\text { Eh } \\
\text { sed } \\
(\mathrm{mV})\end{array}$ & $\begin{array}{c}\mathrm{f}<63 \mu \mathrm{m} \\
(\%)\end{array}$ & $\begin{array}{c}\mathrm{CaCO}_{3} \\
(\%)\end{array}$ & $\begin{array}{c}\text { TOC } \\
(\%)\end{array}$ & $\begin{array}{c}\mathrm{Fe} \\
\left(\mathrm{mg} \cdot \mathrm{g}^{-1}\right)\end{array}$ & $\begin{array}{c}\mathrm{Al} \\
\left(\mathrm{mg} \cdot \mathrm{g}^{-1}\right)\end{array}$ & $\begin{array}{c}\mathrm{Mn} \\
\left(\mu \mathrm{g} \cdot \mathrm{g}^{-1}\right)\end{array}$ & $\begin{array}{c}\text { As } \\
\left(\mu \mathrm{g} \cdot \mathrm{g}^{-1}\right)\end{array}$ & $\underset{\left(\mu \mathrm{g} \cdot \mathrm{g}^{-1}\right)}{\mathrm{Cd}}$ & $\begin{array}{c}\text { Co } \\
\left(\mu \mathrm{g} \cdot \mathrm{g}^{-1}\right)\end{array}$ & $\begin{array}{c}\mathrm{Cr} \\
\left(\mu \mathrm{g} \cdot \mathrm{g}^{-1}\right)\end{array}$ & $\begin{array}{c}\mathrm{Cu} \\
\left(\mu \mathrm{g} \cdot \mathrm{g}^{-1}\right)\end{array}$ & $\underset{\left(\mu \mathrm{g} \cdot \mathrm{g}^{-1}\right)}{\mathrm{Hg}}$ & $\begin{array}{c}\mathrm{Ni} \\
\left(\mu \mathrm{g} \cdot \mathrm{g}^{-1}\right)\end{array}$ & $\begin{array}{c}\mathrm{Pb} \\
\left(\mu \mathrm{g} \cdot \mathrm{g}^{-1}\right)\end{array}$ & $\underset{\left(\mu \mathrm{g} \cdot \mathrm{g}^{-1}\right)}{\mathrm{Zn}}$ \\
\hline $\mathrm{RN}$ & 7.07 & -127 & 90 & 38 & 1.88 & $20 \pm 2$ & $45.5 \pm 0.7$ & $426 \pm 35$ & $6.3 \pm 0.2$ & $0.25 \pm 0.05$ & $7.8 \pm 0.8$ & $56 \pm 3$ & $21 \pm 2$ & $0.13 \pm 0.01$ & $29 \pm 3$ & $16.7 \pm 0.7$ & $82 \pm 6$ \\
\hline B1 & 7.41 & -206 & 70 & 46 & 2.07 & $20.4 \pm 0.2$ & $39.8 \pm 0.7$ & $505 \pm 3$ & $10.4 \pm 0.4$ & $0.23 \pm 0.01$ & $7.5 \pm 1.1$ & $43 \pm 3$ & $16.8 \pm 0.6$ & $0.068 \pm 0.002$ & $26.0 \pm 0.4$ & $15.7 \pm 1.0$ & $90 \pm 7$ \\
\hline B2 & 7.45 & -126 & 51 & 49 & 2.66 & $19.3 \pm 0.3$ & $37.9 \pm 0.1$ & $372 \pm 4$ & $8.4 \pm 1.3$ & $0.29 \pm 0.09$ & $6.4 \pm 0.2$ & $40 \pm 1$ & $28 \pm 1$ & $0.127 \pm 0.003$ & $22 \pm 3$ & $25.5 \pm 0.8$ & $125 \pm 22$ \\
\hline B3 & 7.30 & -214 & 91 & 44 & 1.76 & $27.4 \pm 0.3$ & $60.2 \pm 0.6$ & $579 \pm 10$ & $8.9 \pm 2.1$ & $0.28 \pm 0.10$ & $7.1 \pm 0.2$ & $58 \pm 1$ & $23 \pm 2$ & $0.130 \pm 0.003$ & $32 \pm 5$ & $21 \pm 3$ & $107 \pm 23$ \\
\hline B5 & 7.57 & -202 & 68 & 53 & 3.55 & $18.9 \pm 0.5$ & $41.7 \pm 0.3$ & $410 \pm 11$ & $7.6 \pm 1.7$ & $0.36 \pm 0.10$ & $6.8 \pm 0.3$ & $46 \pm 3$ & $21 \pm 3$ & $0.147 \pm 0.004$ & $26 \pm 5$ & $22 \pm 2$ & $122 \pm 13$ \\
\hline B7 & 7.76 & -141 & 41 & 50 & 2.23 & $15.1 \pm 0.1$ & $31.3 \pm 0.3$ & $349 \pm 2$ & $7.9 \pm 1.4$ & $0.36 \pm 0.12$ & $5.3 \pm 0.1$ & $40 \pm 3$ & $19 \pm 4$ & $0.121 \pm 0.003$ & $20 \pm 4$ & $24 \pm 2$ & $102 \pm 28$ \\
\hline B8 & 7.54 & -116 & 85 & 45 & 2.12 & $21.2 \pm 0.5$ & $45.9 \pm 0.3$ & $448 \pm 10$ & $6.8 \pm 0.7$ & $0.37 \pm 0.14$ & $6.8 \pm 0.5$ & $52 \pm 4$ & $25 \pm 1$ & $0.725 \pm 0.019$ & $29 \pm 1$ & $26.8 \pm 0.1$ & $120 \pm 18$ \\
\hline B9 & 7.65 & -125 & 54 & 49 & 2.24 & $16.1 \pm 0.7$ & $32.8 \pm 0.2$ & $348 \pm 15$ & $8.6 \pm 0.9$ & $0.34 \pm 0.11$ & $5.27 \pm 0.03$ & $41.5 \pm 0.9$ & $20 \pm 2$ & $0.154 \pm 0.004$ & $21 \pm 3$ & $25.6 \pm 0.5$ & $112 \pm 39$ \\
\hline $\mathrm{B} 12$ & 7.50 & -158 & 69 & 57 & 2.98 & $16.7 \pm 0.2$ & $38.4 \pm 0.3$ & $307 \pm 6$ & $5.8 \pm 1.9$ & $0.32 \pm 0.10$ & $6.0 \pm 0.3$ & $43.1 \pm 0.1$ & $22 \pm 4$ & $0.128 \pm 0.003$ & $21.4 \pm 0.8$ & $22 \pm 4$ & $114 \pm 33$ \\
\hline B13 & 7.22 & -175 & 81 & 51 & 2.20 & $18.2 \pm 0.3$ & $33.6 \pm 0.1$ & $384 \pm 3$ & $5.6 \pm 0.7$ & $0.24 \pm 0.08$ & $5.68 \pm 0.03$ & $44.7 \pm 0.6$ & $19 \pm 2$ & $0.085 \pm 0.002$ & $24 \pm 2$ & $16.4 \pm 1.0$ & $121 \pm 35$ \\
\hline VA & 7.22 & -184 & 81 & 42 & 1.82 & $9.9 \pm 0.9$ & $23 \pm 1$ & $267 \pm 21$ & $4.8 \pm 0.2$ & $0.49 \pm 0.08$ & $5.4 \pm 0.5$ & $46 \pm 1$ & $17 \pm 1$ & $0.15 \pm 0.01$ & $16.9 \pm 0.1$ & $46 \pm 2$ & $72 \pm 4$ \\
\hline VC & 7.12 & -196 & 88 & 44 & 3.17 & $14.2 \pm 1.2$ & $29.7 \pm 0.5$ & $262 \pm 15$ & $7.7 \pm 0.3$ & $0.75 \pm 0.09$ & $7.3 \pm 0.7$ & $77 \pm 6$ & $29 \pm 4$ & $0.25 \pm 0.02$ & $30.5 \pm 0.8$ & $47 \pm 1$ & $121 \pm 6$ \\
\hline $\mathrm{VN}$ & 7.35 & -126 & 59 & 49 & 3.60 & $15.4 \pm 0.9$ & $31.4 \pm 0.3$ & $289 \pm 13$ & $8.9 \pm 0.4$ & $0.68 \pm 0.06$ & $7.8 \pm 0.8$ & $74 \pm 1$ & $30 \pm 1$ & $0.27 \pm 0.01$ & $31.8 \pm 0.3$ & $51 \pm 2$ & $166 \pm 13$ \\
\hline B10 & 7.65 & -199 & 86 & 54 & 3.70 & $19.6 \pm 0.1$ & $35.3 \pm 0.3$ & $303 \pm 3$ & $10 \pm 2$ & $1.07 \pm 0.35$ & $7.5 \pm 0.2$ & $72 \pm 4$ & $35 \pm 5$ & $0.317 \pm 0.008$ & $34 \pm 5$ & $98 \pm 13$ & $239 \pm 22$ \\
\hline B11 & 7.40 & -190 & 94 & 43 & 4.07 & $21.0 \pm 0.4$ & $37.7 \pm 0.3$ & $329 \pm 6$ & $11.9 \pm 0.8$ & $1.35 \pm 0.32$ & $8.2 \pm 0.1$ & $100 \pm 3$ & $44 \pm 1$ & $0.43 \pm 0.01$ & $36 \pm 1$ & $74 \pm 0.7$ & $220 \pm 52$ \\
\hline NGB & & & & & & & & & $5.6 \pm 2.0$ & $0.12 \pm 0.01$ & & $47 \pm 10$ & $11 \pm 2$ & $0.14 \pm 0.03$ & $18 \pm 3$ & $11 \pm 4$ & $80 \pm 28$ \\
\hline
\end{tabular}


Table 2: Mean percentage ( \pm standard deviation) of major and trace elements in sediment extracts using EDTA and ascorbate, ranked in descending order for EDTA. The Pearson correlation coefficient $\left(\mathrm{r}^{2}\right)$ between the elements extracted by EDTA and ascorbate is also reported. Values in bold correspond to significant correlations at the 0.05 level.

\begin{tabular}{|c|c|c|c|}
\hline & $\begin{array}{l}\text { EDTA } \\
(n=15)\end{array}$ & $\begin{array}{c}\text { ASCORBATE } \\
(\mathrm{n}=11)\end{array}$ & $\begin{array}{c}\mathrm{r}^{2} \\
(\mathrm{n}=11)\end{array}$ \\
\hline \multicolumn{4}{|c|}{ MAJOR ELEMENTS } \\
\hline $\mathrm{Ca}$ & $106 \pm 7$ & $2.6 \pm 0.5$ & 0.00 \\
\hline Mn & $73 \pm 8$ & $6 \pm 3$ & 0.43 \\
\hline $\mathrm{Mg}$ & $29 \pm 7$ & $9 \pm 2$ & 0.52 \\
\hline $\mathrm{P}$ & $24 \pm 4$ & $27 \pm 7$ & 0.68 \\
\hline $\mathrm{S}$ & $15 \pm 6$ & $11 \pm 4$ & 0.90 \\
\hline $\mathrm{Fe}$ & $12 \pm 3$ & $12 \pm 3$ & 0.74 \\
\hline $\mathrm{Al}$ & $0.09 \pm 0.04$ & $0.22 \pm 0.05$ & 0.55 \\
\hline \multicolumn{4}{|c|}{ TRACES ELEMENTS } \\
\hline $\mathrm{Pb}$ & $66 \pm 12$ & $3 \pm 2$ & 0.18 \\
\hline $\mathrm{Cu}$ & $38 \pm 10$ & $<1$ & n.d. \\
\hline $\mathrm{Cd}$ & $32 \pm 13$ & $<1$ & n.d. \\
\hline As & $18 \pm 3$ & $29 \pm 5$ & 0.88 \\
\hline $\mathrm{Co}$ & $18 \pm 6$ & $15 \pm 3$ & 0.76 \\
\hline $\mathrm{Zn}$ & $17 \pm 5$ & $25 \pm 6$ & 0.62 \\
\hline $\mathrm{Ni}$ & $11 \pm 4$ & $12 \pm 4$ & 0.98 \\
\hline $\mathrm{Cr}$ & $4 \pm 2$ & $5 \pm 3$ & 0.98 \\
\hline
\end{tabular}

Table 3: Pearson correlation matrix for the concentrations of major and trace elements in Alitta succinea tissues. The shaded lines and columns correspond to elements that have been localized in the tissues of organisms by $\mu$ XRF. Values in bold correspond to significant correlations at the 0.05 level.

\begin{tabular}{|c|c|c|c|c|c|c|c|c|c|c|c|c|c|c|c|c|}
\hline & $\mathrm{Ca}$ & $\mathrm{Mg}$ & $\mathrm{P}$ & $\mathrm{S}$ & $\mathrm{Al}$ & $\mathrm{Fe}$ & $\mathrm{Mn}$ & As & $\mathrm{Cd}$ & Co & $\mathrm{Cr}$ & $\mathrm{Cu}$ & $\mathrm{Hg}$ & $\mathrm{Ni}$ & $\mathrm{Pb}$ & $\mathrm{Zn}$ \\
\hline $\mathrm{Ca}$ & 1 & & & & & & & & & & & & & & & \\
\hline $\mathrm{Mg}$ & 0.41 & 1 & & & & & & & & & & & & & & \\
\hline $\mathrm{P}$ & 0.33 & 0.64 & 1 & & & & & & & & & & & & & \\
\hline S & 0.53 & 0.70 & 0.85 & 1 & & & & & & & & & & & & \\
\hline $\mathrm{Al}$ & 0.74 & 0.22 & 0.23 & 0.39 & 1 & & & & & & & & & & & \\
\hline $\mathrm{Fe}$ & 0.71 & 0.37 & 0.14 & 0.41 & 0.73 & 1 & & & & & & & & & & \\
\hline $\mathrm{Mn}$ & 0.76 & 0.36 & 0.23 & 0.33 & 0.76 & 0.75 & 1 & & & & & & & & & \\
\hline As & 0.39 & 0.72 & 0.79 & 0.91 & 0.24 & 0.30 & 0.16 & 1 & & & & & & & & \\
\hline $\mathrm{Cd}$ & -0.16 & 0.33 & 0.11 & 0.10 & -0.24 & 0.04 & 0.01 & 0.36 & 1 & & & & & & & \\
\hline $\mathrm{Co}$ & 0.25 & 0.72 & 0.32 & 0.60 & 0.30 & 0.59 & 0.23 & 0.62 & 0.28 & 1 & & & & & & \\
\hline $\mathrm{Cr}$ & 0.29 & 0.41 & 0.22 & 0.37 & 0.27 & 0.56 & 0.40 & 0.43 & 0.71 & 0.54 & 1 & & & & & \\
\hline $\mathrm{Cu}$ & 0.16 & 0.26 & -0.02 & 0.08 & 0.01 & 0.41 & 0.23 & 0.24 & 0.78 & 0.29 & 0.79 & 1 & & & & \\
\hline $\mathrm{Hg}$ & -0.01 & 0.13 & -0.16 & -0.02 & -0.23 & 0.38 & 0.11 & -0.01 & 0.42 & 0.14 & 0.37 & 0.67 & 1 & & & \\
\hline $\mathrm{Ni}$ & 0.60 & 0.44 & 0.48 & 0.68 & 0.46 & 0.71 & 0.37 & 0.70 & 0.20 & 0.52 & 0.54 & 0.36 & 0.39 & 1 & & \\
\hline $\mathrm{Pb}$ & 0.07 & 0.39 & 0.16 & 0.30 & -0.05 & 0.19 & 0.01 & 0.54 & 0.85 & 0.44 & 0.76 & 0.63 & 0.25 & 0.50 & 1 & \\
\hline $\mathrm{Zn}$ & 0.30 & 0.62 & 0.36 & 0.65 & 0.35 & 0.66 & 0.28 & 0.68 & 0.37 & 0.93 & 0.63 & 0.47 & 0.26 & 0.60 & 0.47 & 1 \\
\hline
\end{tabular}




\section{FIGURES CAPTION}

Figure 1: Location of sampling sites in surface sediments of the Berre lagoon. The shaded area represents the area subject to anoxia events in the water column where macrobenthic organisms are absent.

Figure 2: Examples of $\mathrm{Cd}, \mathrm{Hg}$ and $\mathrm{Pb}$ total concentrations in surface sediments in the Central basin (white bars) and the Vaïne basin (grey bars). The horizontal bar represents the Natural Geochemical background for the area.

Figure 3: Examples of $\mathrm{Cr}, \mathrm{Pb}$ and $\mathrm{Zn}$ concentrations extracted by EDTA and ascorbate in surface sediments. The vertical line delimits the separation between the Central basin (left) and the Vaine basin (right).

Figure 4: Concentrations of major (Al, Mg, Mn, Fe, Ca, S) and trace elements in the tissues of Alitta succinea collected in the Central basin (white bars) and the Vaïne basin (grey bars). The dashed horizontal lines represent the minimum and maximum values reported in the literature for the polychaete Hediste diversicolor. When the value is out of the range of the plots, it is indicated with an arrow.

Figure 5: Transmission image, and $\mu$ XRF elemental mapping (K-line) of the head (upper pannel) and body (bottom pannel) of polychaete Alitta succinea.

Figure 6: Examples of significant correlations obtained for the total concentrations of elements in the tissues of Alitta succinea. The gray points are excluded from the regression. The dashed lines correspond to $20 \%$ interval around the main regression line.

Figure 7: Comparison of $\mathrm{Cd} / \mathrm{S}$ and $\mathrm{Pb} / \mathrm{Ca}$ concentrations ratios in Alitta Succinea with concentrations extracted by EDTA from sediment.

Figure 8: Density (left) and specific diversity (right) of the benthic macrofauna in June 2010 (GIPREB, personal communication). For the density, bivalves, crustaceans and polychaetes are distinguished. 


\section{FIGURES}

Figure 1

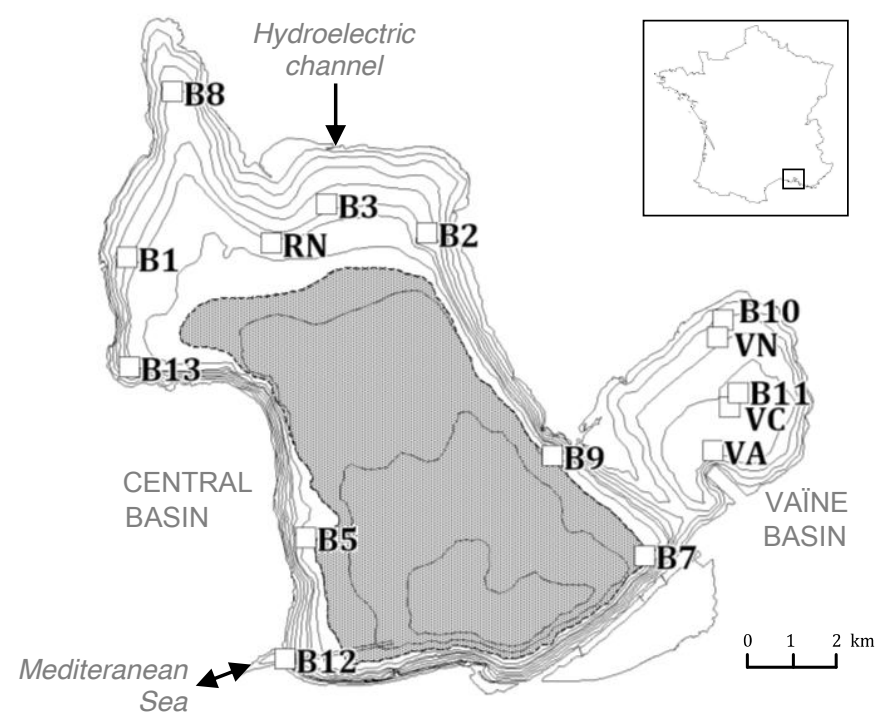

Figure 2
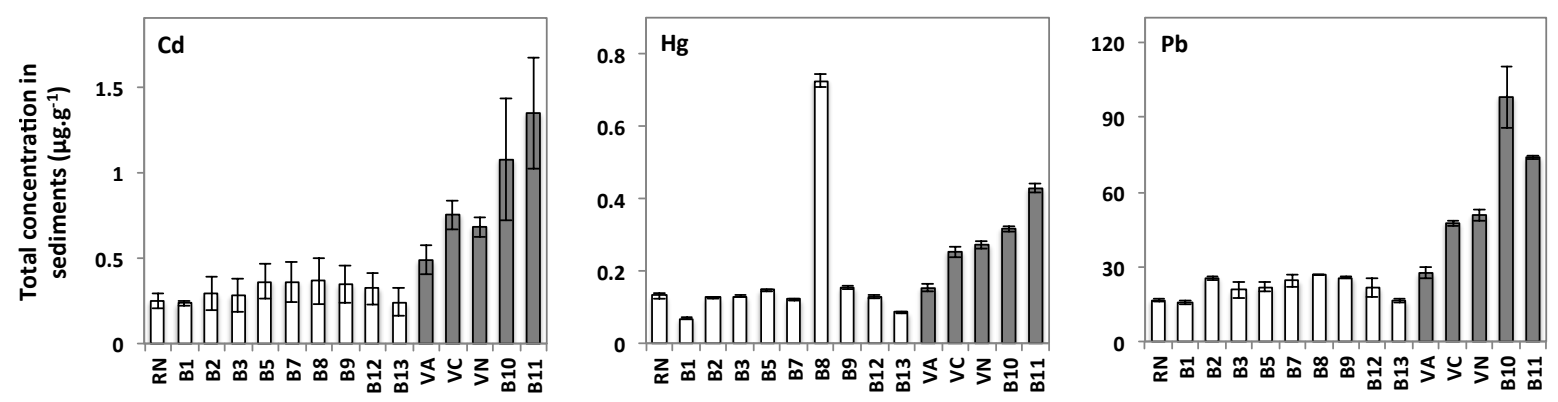

Figure 3
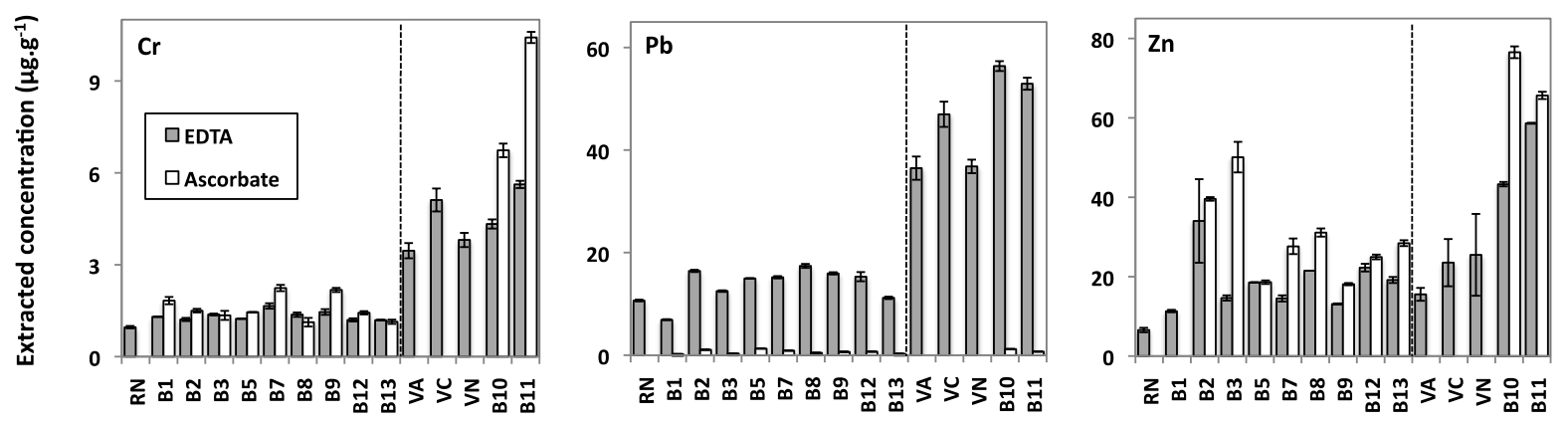
Figure 4
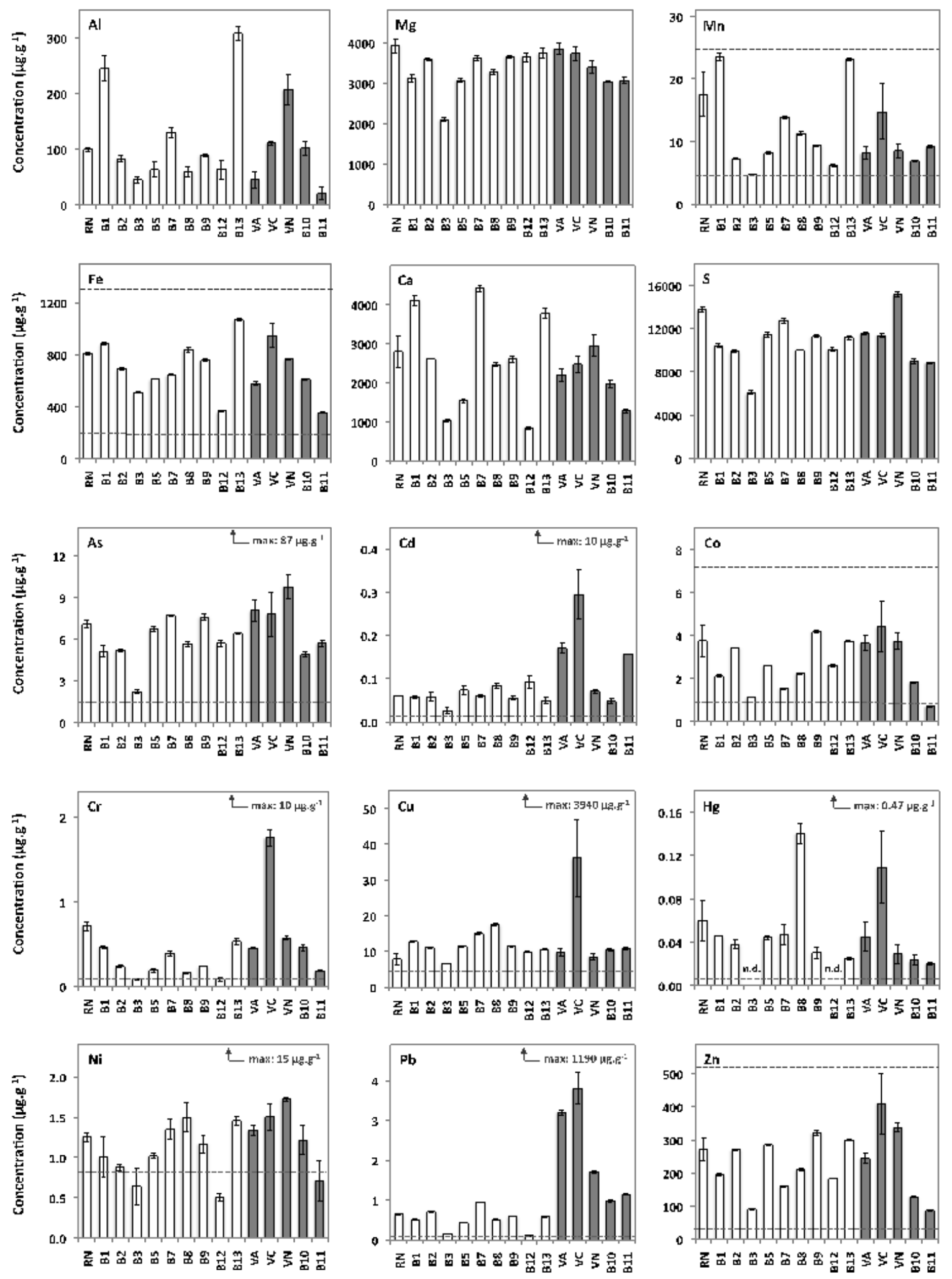
Figure 5
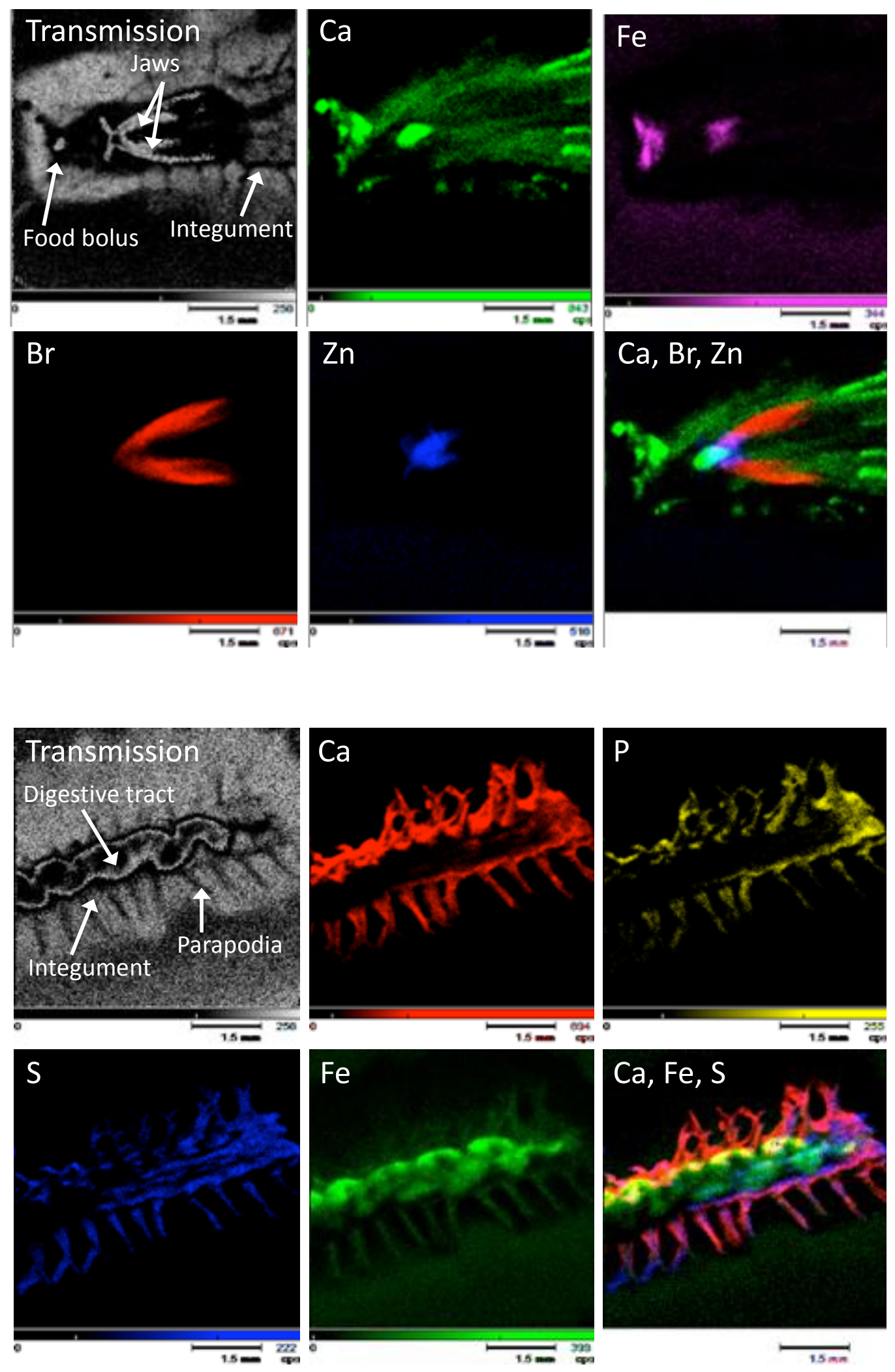

$\mathrm{Ca}, \mathrm{Fe}, \mathrm{S}$
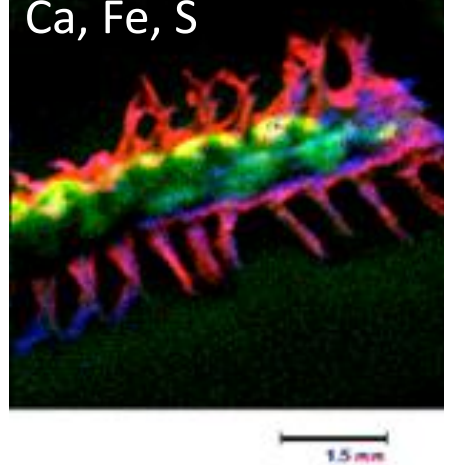
Figure 6
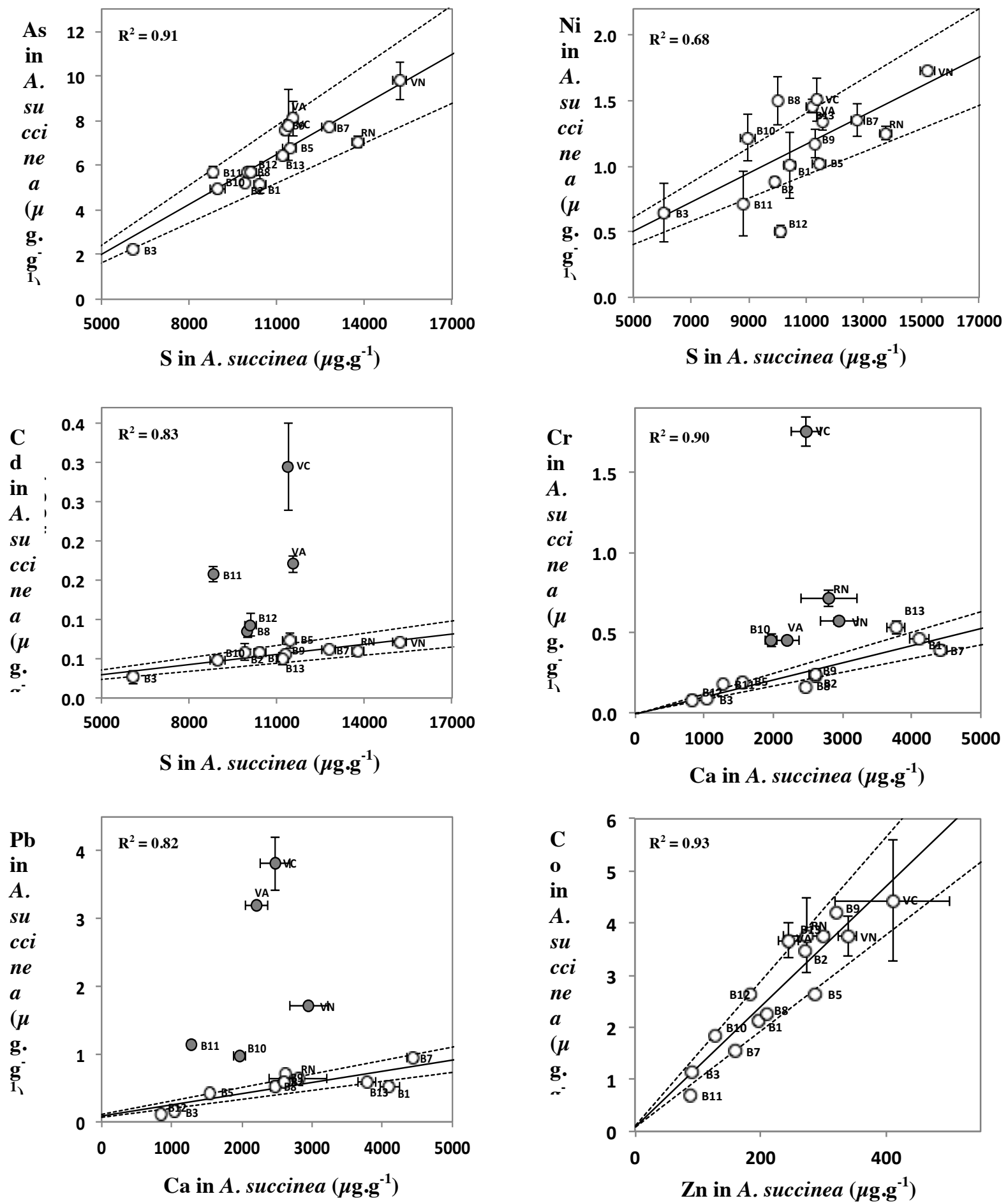
Figure 7

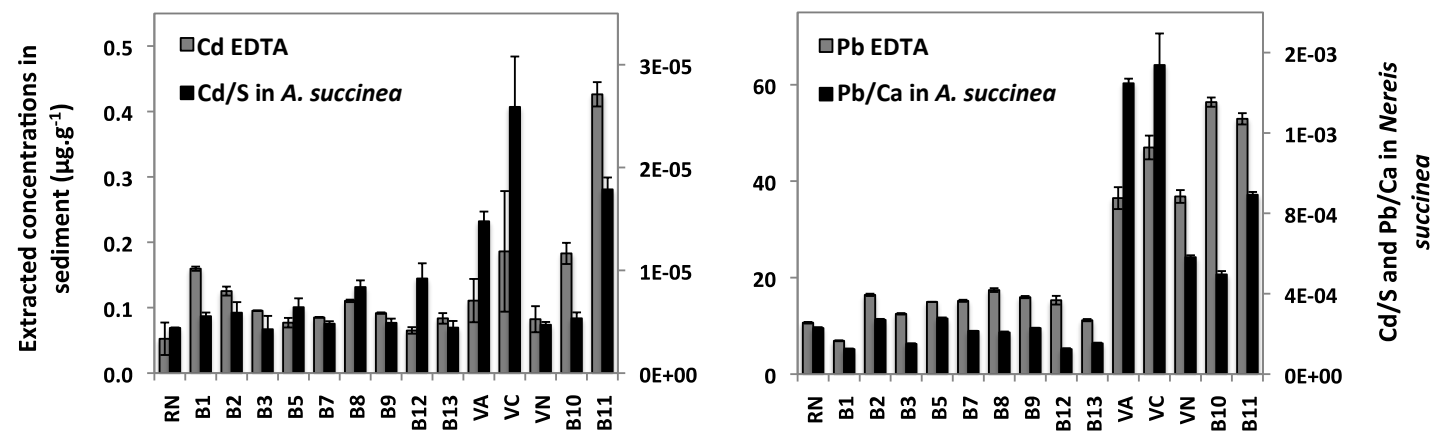

Figure 8
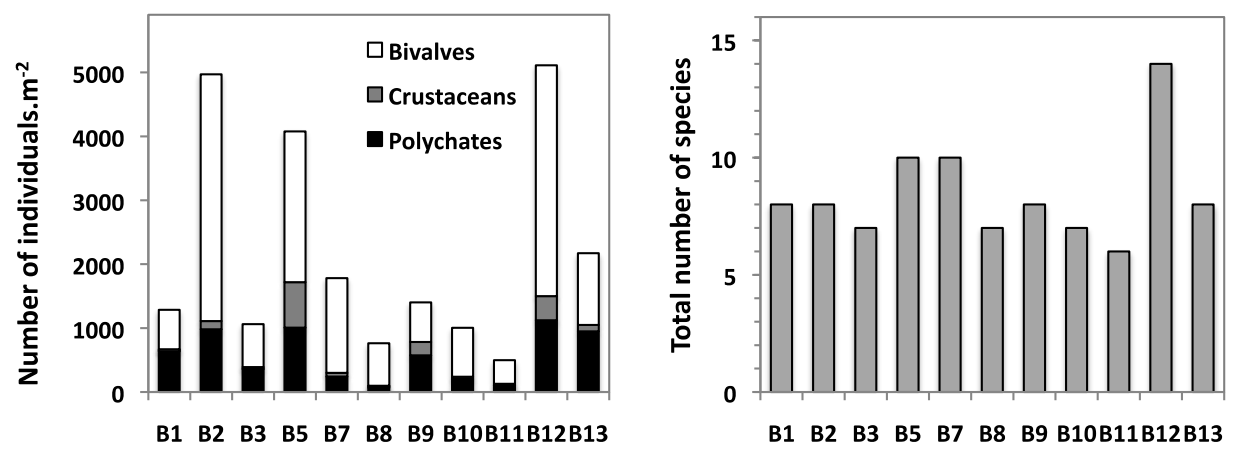


\section{APPENDIX}

Table A1: Concentrations of the potentially bioavailable fraction of trace elements in sediment obtained using EDTA and ascorbate extractions. Concentration of major elements extracted are also reported.

\begin{tabular}{|c|c|c|c|c|c|c|c|c|c|c|c|c|c|c|c|c|}
\hline Sites & $\begin{array}{c}\mathrm{Ca} \\
\left(\mathrm{mg} \cdot \mathrm{g}^{-1}\right)\end{array}$ & $\underset{\left(m g \cdot g^{-1}\right)}{M g}$ & $\begin{array}{c}\mathrm{P} \\
\left(\mathrm{mg} \cdot \mathrm{g}^{-1}\right)\end{array}$ & $\begin{array}{c}\mathrm{S} \\
\left(\mathrm{mg} \cdot \mathrm{g}^{-1}\right)\end{array}$ & $\begin{array}{c}\mathrm{Fe} \\
\left(\mathrm{mg} \cdot \mathrm{g}^{-1}\right)\end{array}$ & $\underset{\left(\mu \mathrm{g} \cdot \mathrm{g}^{-1}\right)}{\mathrm{Al}}$ & $\begin{array}{c}\mathrm{Mn} \\
\left(\mu \mathrm{g} \cdot \mathrm{g}^{-1}\right)\end{array}$ & $\begin{array}{c}\text { As } \\
\left(\mu g \cdot g^{-1}\right)\end{array}$ & $\begin{array}{c}\mathrm{Cd} \\
\left(\mu \mathrm{g} \cdot \mathrm{g}^{-1}\right)\end{array}$ & $\begin{array}{c}\text { Co } \\
\left(\mu g \cdot g^{-1}\right)\end{array}$ & $\begin{array}{c}\mathrm{Cr} \\
\left(\mu \mathrm{g} \cdot \mathrm{g}^{-1}\right)\end{array}$ & $\begin{array}{c}\mathrm{Cu} \\
\left(\mu \mathrm{g} \cdot \mathrm{g}^{-1}\right)\end{array}$ & $\underset{\left(\mu \mathrm{g} \cdot \mathrm{g}^{-1}\right)}{\mathrm{Hg}}$ & $\begin{array}{c}\mathrm{Ni} \\
\left(\mu \mathrm{g} \cdot \mathrm{g}^{-1}\right)\end{array}$ & $\begin{array}{c}\mathrm{Pb} \\
\left(\mu \mathrm{g} \cdot \mathrm{g}^{-1}\right)\end{array}$ & $\underset{\left(\mu \mathrm{gn} \cdot \mathrm{g}^{-1}\right)}{\mathrm{Zn}}$ \\
\hline RN EDTA & $97.0 \pm 0.1$ & n.d. & n.d. & n.d. & $3.18 \pm 0.05$ & $7 \pm 1$ & $215 \pm 2$ & $0.68 \pm 0.02$ & $0.05 \pm 0.02$ & $0.4 \pm 0.2$ & $0.96 \pm 0.04$ & $1.8 \pm 0.3$ & n.d. & $1.6 \pm 0.1$ & $10.7 \pm 0.2$ & $6.6 \pm 0.6$ \\
\hline B1 EDTA & $176 \pm 5$ & $2.96 \pm 0.09$ & $166 \pm 30$ & $1095 \pm 4$ & $1.34 \pm 0.06$ & $38 \pm 4$ & $383 \pm 9$ & $1.17 \pm 0.06$ & $0.16 \pm 0.01$ & $1.20 \pm 0.05$ & $1.3 \pm 0.1$ & $5.3 \pm 0.2$ & n.d. & $1.9 \pm 0.1$ & $6.9 \pm 0.1$ & $11.3 \pm 0.3$ \\
\hline B2 EDTA & $187 \pm 2$ & $2.95 \pm 0.02$ & $295 \pm 15$ & $1265 \pm 7$ & $1.81 \pm 0.05$ & $33.7 \pm 0.4$ & $254 \pm 2$ & $1.6 \pm 0.2$ & $0.13 \pm 0.01$ & $1.34 \pm 0.06$ & $1.21 \pm 0.05$ & $12.3 \pm 0.1$ & n.d. & $2.8 \pm 0.1$ & $16.4 \pm 0.2$ & $34 \pm 10$ \\
\hline B3 EDTA & $159 \pm 2$ & $2.36 \pm 0.07$ & $140 \pm 25$ & $1405 \pm 33$ & $3.20 \pm 0.16$ & $47 \pm 12$ & & $1.6 \pm 0.1$ & & $1.08 \pm 0.04$ & $1.38 \pm 0.03$ & & n.d. & & & $14.6 \pm 0.7$ \\
\hline B5 EDTA & $199 \pm 4$ & $3.72 \pm 0.07$ & $295 \pm 5$ & $1961 \pm 76$ & $2.40 \pm 0.04$ & $23 \pm 1$ & $298 \pm 5$ & $1.59 \pm 0.01$ & $0.08 \pm 0.01$ & $1.67 \pm 0.01$ & $1.24 \pm 0.01$ & $9.9 \pm 0.1$ & n.d. & $3.7 \pm 0.1$ & $5.0 \pm 0.1$ & $18.6 \pm 0.1$ \\
\hline B7 EDTA & $181 \pm 5$ & $2.83 \pm 0.07$ & $177 \pm 4$ & $1344 \pm 57$ & $1.47 \pm 0.07$ & $17 \pm 5$ & $232 \pm 4$ & $1.3 \pm 0.1$ & $0.09 \pm 0.01$ & $1.09 \pm 0.09$ & $1.65 \pm 0.09$ & $7.2 \pm 0.4$ & n.d. & $2.3 \pm 0.1$ & $15.2 \pm 0.2$ & $14.5 \pm 0.8$ \\
\hline B8 EDTA & $166 \pm 1$ & $2.59 \pm 0.03$ & $195 \pm 7$ & $1509 \pm 27$ & $2.65 \pm 0.05$ & $35 \pm 1$ & $321 \pm 4$ & $1.0 \pm 0.1$ & $0.11 \pm 0.01$ & $0.71 \pm 0.03$ & $1.37 \pm 0.07$ & $10.8 \pm 0.6$ & n.d. & $2.0 \pm 0.2$ & $17.4 \pm 0.4$ & $21.5 \pm 0.1$ \\
\hline B9 EDTA & $180 \pm 4$ & $2.34 \pm 0.05$ & $184 \pm 8$ & $1174 \pm 45$ & $1.50 \pm 0.02$ & $14 \pm 3$ & $211 \pm 6$ & $1.3 \pm 0.1$ & $0.09 \pm 0.01$ & $1.07 \pm 0.01$ & $1.5 \pm 0.1$ & $7.2 \pm 0.2$ & n.d. & $2.2 \pm 0.1$ & $16.0 \pm 0.2$ & $13.1 \pm 0.2$ \\
\hline B12 EDTA & $219 \pm 3$ & $3.76 \pm 0.05$ & $191 \pm 12$ & $2316 \pm 126$ & $2.87 \pm 0.02$ & $14 \pm 2$ & $222 \pm 3$ & .01 & $0.07 \pm 0.01$ & $1.43 \pm 0.01$ & $1.20 \pm 0.05$ & $9 \pm 0.3$ & n.d. & & 15. & $22 \pm 1$ \\
\hline B13 EDTA & $194 \pm 4$ & & $171 \pm 17$ & $1529 \pm 23$ & $2.71 \pm 0.05$ & $29 \pm 2$ & & & & & & & n.d. & & & \\
\hline VA EDTA & $127 \pm 1$ & n.d. & n.d. & n.d. & $1.68 \pm 0.03$ & $17 \pm 2$ & $134.1 \pm 0.1$ & $1.15 \pm 0.01$ & $0.11 \pm 0.03$ & $0.7 \pm 0.3$ & $3.5 \pm 0.3$ & $6.5 \pm 0.3$ & n.d. & $2.0 \pm 0.2$ & $37 \pm 2$ & $16 \pm 2$ \\
\hline VC EDTA & $134 \pm 3$ & n.d. & n.d. & n.d. & $2.38 \pm 0.12$ & $35 \pm 7$ & $140 \pm 1$ & $1.4 \pm 0.3$ & $0.19 \pm 0.09$ & $0.64 \pm 0.04$ & $5.1 \pm 0.4$ & $12.5 \pm 4.6$ & n.d. & $2.6 \pm 0.1$ & $47 \pm 3$ & $24 \pm 6$ \\
\hline VN EDTA & $148 \pm 3$ & n.d. & n.d. & n.d. & $2.08 \pm 0.33$ & $26 \pm 4$ & $163 \pm 7$ & $1.14 \pm 0.01$ & $0.08 \pm 0.02$ & $1.44 \pm 1.25$ & $3.8 \pm 0.2$ & $6.4 \pm 1.1$ & n.d. & $3.2 \pm 0.9$ & $37 \pm 1$ & $25 \pm 10$ \\
\hline B10 EDTA & $205 \pm 5$ & $3.69 \pm 0.09$ & $227 \pm 5$ & $2041 \pm 99$ & $2.35 \pm 0.07$ & $38 \pm 1$ & $182 \pm 5$ & $2.06 \pm 0.02$ & $0.18 \pm 0.02$ & $1.57 \pm 0.03$ & $4.3 \pm 0.2$ & $13.8 \pm 0.2$ & n.d. & $4.7 \pm 0.1$ & $56 \pm 1$ & $43.3 \pm 0.6$ \\
\hline B11 EDTA & $159 \pm 4$ & $2.98 \pm 0.07$ & $172 \pm 18$ & $1667 \pm 29$ & $1.65 \pm 0.06$ & $55 \pm 1$ & $164 \pm 6$ & $2.4 \pm 0.1$ & $0.43 \pm 0.02$ & $1.91 \pm 0.05$ & $5.6 \pm 0.1$ & $21.5 \pm 0.2$ & n.d. & $6.3 \pm 0.2$ & $53 \pm 1$ & $58.6 \pm 0.1$ \\
\hline RN ASC & n.d. & n.d. & n.d. & n.d. & nd & nd & n.d. & n.d. & n.d. & n.d. & n.d. & n.d. & n.d. & n.d. & n.d. & n.d. \\
\hline B1 ASC & $4.54 \pm 0.02$ & $1.14 \pm 0.01$ & $241 \pm 19$ & $745 \pm 12$ & $1.37 \pm 0.01$ & $68 \pm 3$ & $41 \pm 1$ & $1.9 \pm 0.2$ & $<$ q.I. & $0.89 \pm 0.04$ & $1.8 \pm 0.1$ & $<$ q.I. & n.d. & $1.7 \pm 0.2$ & $0.21 \pm 0.01$ & $125 \pm 3$ \\
\hline B2 ASC & $4.50 \pm 0.03$ & $1.36 \pm 0.01$ & $303 \pm 20$ & $932 \pm 25$ & $1.99 \pm 0.02$ & $87 \pm 4$ & $31 \pm 1$ & $2.3 \pm 0.2$ & $<$ q.I. & $1.04 \pm 0.05$ & $1.50 \pm 0.06$ & $<$ q.I. & n.d. & $2.8 \pm 0.1$ & $1.05 \pm 0.02$ & $39.6 \pm 0.4$ \\
\hline B3 ASC & $4.23 \pm 0.04$ & $1.16 \pm 0.01$ & $144 \pm 1$ & $1121 \pm 31$ & $2.71 \pm 0.02$ & $80 \pm 9$ & & $2.5 \pm 0.2$ & $<q . I$ & & $1.4 \pm 0.2$ & $<q . I$ & n.d. & & & $50 \pm 4$ \\
\hline B5 ASC & $4.43 \pm 0.03$ & $1.48 \pm 0.06$ & $316 \pm 9$ & $1414 \pm 39$ & 3.14 & $70 \pm 2$ & 43 & 2.74 & $<q . I$ & 1.4 & 1.4 & $<q . I$ & n.d. & $3.9 \pm 0.1$ & $1.28 \pm 0.01$ & $18.6 \pm 0.4$ \\
\hline B7 ASC & $4.35 \pm 0.03$ & $1.15 \pm 0.02$ & $205 \pm 5$ & $1011 \pm 15$ & $1.72 \pm 0.02$ & $76 \pm 8$ & $23 \pm 1$ & $2.2 \pm 0.1$ & $<$ q.I. & $0.80 \pm 0.08$ & $2.2 \pm 0.1$ & $<q . I$. & n.d. & $2.3 \pm 0.2$ & $0.89 \pm 0.07$ & $28 \pm 2$ \\
\hline B8 ASC & $4.63 \pm 0.02$ & $1.26 \pm 0.02$ & $172 \pm 14$ & $1221 \pm 26$ & $2.36 \pm 0.05$ & $68 \pm 5$ & $23.3 \pm 0.1$ & $1.8 \pm 0.1$ & $<q . I$ & $0.59 \pm 0.02$ & $1.1 \pm 0.1$ & $<q . I$ & n.d. & $2.0 \pm 0.2$ & $0.45 \pm 0.01$ & $31 \pm 1$ \\
\hline B9 ASC & $4.77 \pm 0.02$ & $1.08 \pm 0.02$ & $177 \pm 20$ & $909 \pm 28$ & $1.82 \pm 0.04$ & $52 \pm 1$ & $20 \pm 1$ & $2.1 \pm 0.2$ & $<\mathrm{q} . \mathrm{I}$ & $0.74 \pm 0.01$ & $2.18 \pm 0.07$ & <q.I. & n.d. & $2.3 \pm 0.2$ & $0.65 \pm 0.01$ & $18.1 \pm 0.3$ \\
\hline B12 ASC & $5.47 \pm 0.05$ & $1.49 \pm 0.01$ & $190 \pm 9$ & $1765 \pm 50$ & $2.80 \pm 0.01$ & $61 \pm 3$ & $10 \pm 2$ & $2.1 \pm 0.2$ & $<$ q.I. & $1.08 \pm 0.03$ & $1.43 \pm 0.05$ & $<$ q.I. & n.d. & $4.1 \pm 0.2$ & $0.68 \pm 0.01$ & $25.0 \pm 0.6$ \\
\hline B13 ASC & $2.71 \pm 0.01$ & $1.15 \pm 0.01$ & $241 \pm 7$ & $1367 \pm 5$ & $2.66 \pm 0.02$ & $61 \pm 4$ & $16 \pm 1$ & $1.79 \pm 0.07$ & $<q . I$. & $1.04 \pm 0.03$ & $1.14 \pm 0.07$ & $<q . I$. & n.d. & 0.1 & $0.28 \pm 0.01$ & $28.4 \pm 0.7$ \\
\hline VA ASC & n.d. & n.d. & n.d. & n.d. & n.d. & n.d. & n.d. & n.d. & n.d. & n.d. & n.d. & n.d. & n.d. & n.d. & n.d. & n.d. \\
\hline VC ASC & n.d. & n.d. & n.d. & n.d. & n.d. & n.d. & n.d. & n.d. & n.d. & n.d. & n.d. & n.d. & n.d. & n.d. & n.d. & n.d. \\
\hline VN ASC & n.d. & n.d. & n.d. & n.d. & n.d. & n.d. & n.d. & n.d. & n.d. & n.d. & n.d. & n.d. & n.d. & n.d. & n.d. & n.d. \\
\hline B10 ASC & $3.83 \pm 0.02$ & $1.59 \pm 0.01$ & $219 \pm 22$ & $1532 \pm 43$ & $2.50 \pm 0.01$ & $75 \pm 1$ & $10 \pm 1$ & $3.4 \pm 0.3$ & $<\mathrm{q} . \mathrm{l}$. & $1.04 \pm 0.01$ & $6.7 \pm 0.2$ & $<q . I$. & n.d. & $4.5 \pm 0.1$ & $1.19 \pm 0.03$ & $76 \pm 2$ \\
\hline B11 ASC & $4.48 \pm 0.02$ & $1.70 \pm 0.05$ & $174 \pm 7$ & $1472 \pm 23$ & $1.51 \pm 0.05$ & $98 \pm 1$ & $6 \pm 1$ & $3.31 \pm 0.07$ & $<$ q.I. & $1.21 \pm 0.01$ & $10.4 \pm 0.2$ & $<q . I$. & n.d. & $6.2 \pm 0.2$ & $0.68 \pm 0.01$ & $65.6 \pm 0.9$ \\
\hline
\end{tabular}

n.d.: not determined : $<$ q. l: lower than the limit of quantification 
Figure A1: Scatter plots showing the concentrations of trace elements in A. succinea as a function of trace element concentrations in total sediment and in the potentially bioavailable fraction in sediment obtained using EDTA and ascorbate extractions. n.d.: not determined; $\leq$ q.1.: lower than the limit of quantification
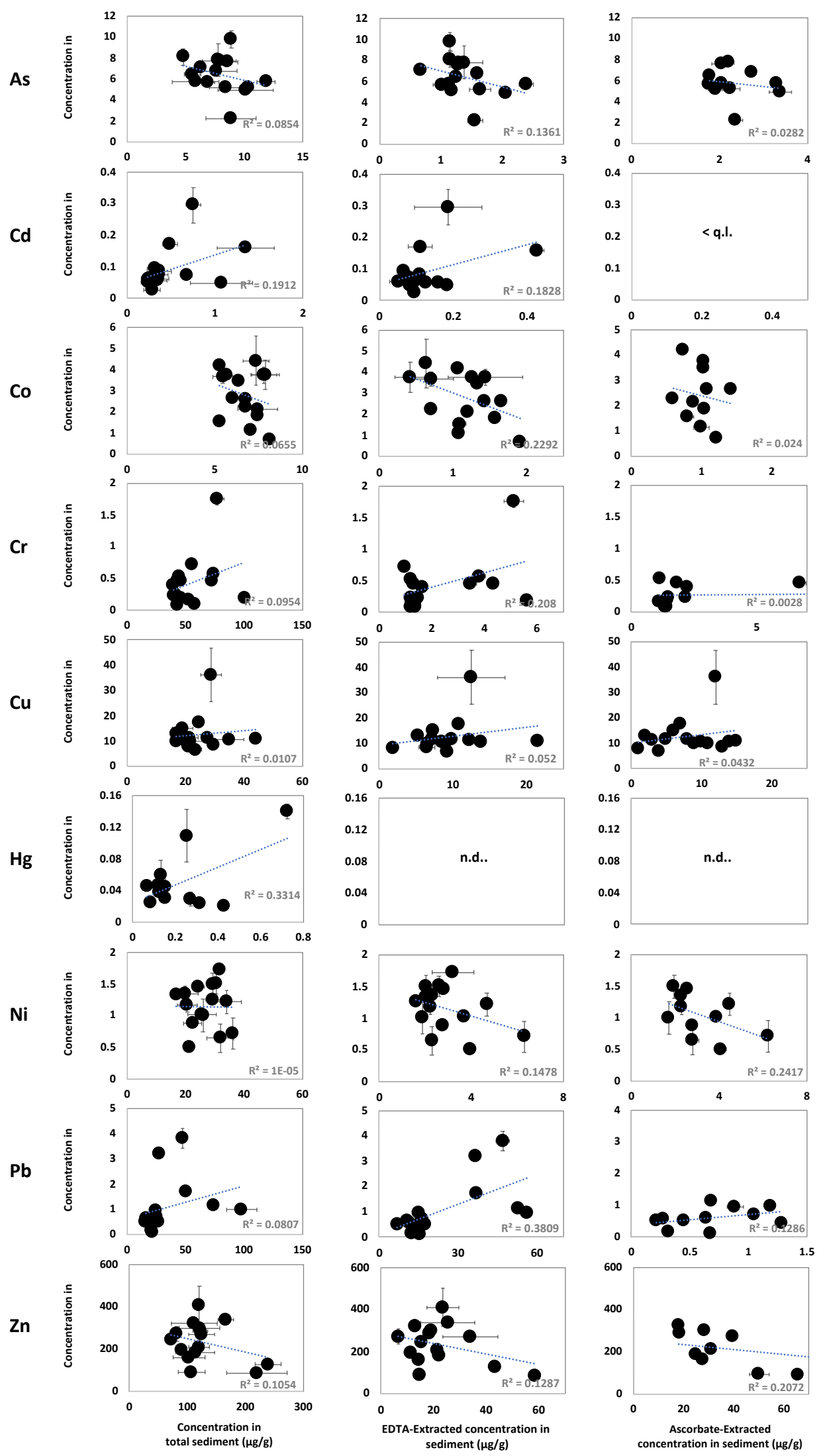


\section{TABLES}

Table 1: $\mathrm{pH}$, Eh (normalized to normal hydrogen electrode), percentage of particles $<63 \mu \mathrm{m}, \mathrm{TOC}$, TIC (expressed as $\% \mathrm{CaCO}_{3}$ ) and total concentrations of major and trace elements in the fraction $<63 \mu \mathrm{m}$ of sediment $( \pm 1$ standard deviation for two replicates). When available, the natural geochemical background (NGB, mean \pm 1 standard deviation) determined in the area from the deepest part of long sediment cores (Giorgetti, 1981; Arnoux, 1987; Georgeaud, 1993; RNO, 1998) is reported.

\begin{tabular}{|c|c|c|c|c|c|c|c|c|c|c|c|c|c|c|c|c|c|}
\hline Sites & $\begin{array}{l}\mathrm{pH} \\
\text { sed }\end{array}$ & $\begin{array}{c}\text { Eh } \\
\text { sed } \\
(\mathrm{mV})\end{array}$ & $\begin{array}{c}\mathrm{f}<63 \mu \mathrm{m} \\
(\%)\end{array}$ & $\begin{array}{c}\mathrm{CaCO}_{3} \\
(\%)\end{array}$ & $\begin{array}{c}\text { TOC } \\
(\%)\end{array}$ & $\begin{array}{c}\mathrm{Fe} \\
\left(\mathrm{mg} \cdot \mathrm{g}^{-1}\right)\end{array}$ & $\begin{array}{c}\mathrm{Al} \\
\left(\mathrm{mg} \cdot \mathrm{g}^{-1}\right)\end{array}$ & $\begin{array}{c}\mathrm{Mn} \\
\left(\mu \mathrm{g} \cdot \mathrm{g}^{-1}\right)\end{array}$ & $\begin{array}{c}\text { As } \\
\left(\mu \mathrm{g} \cdot \mathrm{g}^{-1}\right)\end{array}$ & $\begin{array}{c}\mathrm{Cd} \\
\left(\mu \mathrm{g} \cdot \mathrm{g}^{-1}\right)\end{array}$ & $\begin{array}{c}\text { Co } \\
\left(\mu \mathrm{g} \cdot \mathrm{g}^{-1}\right)\end{array}$ & $\begin{array}{c}\mathrm{Cr} \\
\left(\mu \mathrm{g} \cdot \mathrm{g}^{-1}\right)\end{array}$ & $\begin{array}{c}\mathrm{Cu} \\
\left(\mu \mathrm{g} \cdot \mathrm{g}^{-1}\right)\end{array}$ & $\underset{\left(\mu \mathrm{gg} \cdot \mathrm{g}^{-1}\right)}{\mathrm{Hg}}$ & $\begin{array}{c}\mathrm{Ni} \\
\left(\mu \mathrm{g} \cdot \mathrm{g}^{-1}\right)\end{array}$ & $\begin{array}{c}\mathrm{Pb} \\
\left(\mu \mathrm{g} \cdot \mathrm{g}^{-1}\right)\end{array}$ & $\begin{array}{c}\mathrm{Zn} \\
\left(\mu \mathrm{g} \cdot \mathrm{g}^{-1}\right)\end{array}$ \\
\hline RN & 7.07 & -127 & 90 & 38 & 1.88 & $20 \pm 2$ & $45.5 \pm 0.7$ & $426 \pm 35$ & $6.3 \pm 0.2$ & $0.25 \pm 0.05$ & $7.8 \pm 0.8$ & $56 \pm 3$ & $21 \pm 2$ & $0.13 \pm 0.01$ & $29 \pm 3$ & $16.7 \pm 0.7$ & $82 \pm 6$ \\
\hline B1 & 7.41 & -206 & 70 & 46 & 2.07 & $20.4 \pm 0.2$ & $39.8 \pm 0.7$ & $505 \pm 3$ & $10.4 \pm 0.4$ & $0.23 \pm 0.01$ & $7.5 \pm 1.1$ & $43 \pm 3$ & $16.8 \pm 0.6$ & $0.068 \pm 0.002$ & $26.0 \pm 0.4$ & $15.7 \pm 1.0$ & $90 \pm 7$ \\
\hline B2 & 7.45 & -126 & 51 & 49 & 2.66 & $19.3 \pm 0.3$ & $37.9 \pm 0.1$ & $372 \pm 4$ & $8.4 \pm 1.3$ & $0.29 \pm 0.09$ & $6.4 \pm 0.2$ & $40 \pm 1$ & $28 \pm 1$ & $0.127 \pm 0.003$ & $22 \pm 3$ & $25.5 \pm 0.8$ & $125 \pm 22$ \\
\hline B3 & 7.30 & -214 & 91 & 44 & 1.76 & $27.4 \pm 0.3$ & $60.2 \pm 0.6$ & $579 \pm 10$ & $8.9 \pm 2.1$ & $0.28 \pm 0.10$ & $7.1 \pm 0.2$ & $58 \pm 1$ & $23 \pm 2$ & $0.130 \pm 0.003$ & $32 \pm 5$ & $21 \pm 3$ & $107 \pm 23$ \\
\hline B5 & 7.57 & -202 & 68 & 53 & 3.55 & $18.9 \pm 0.5$ & $41.7 \pm 0.3$ & $410 \pm 11$ & $7.6 \pm 1.7$ & $0.36 \pm 0.10$ & $6.8 \pm 0.3$ & $46 \pm 3$ & $21 \pm 3$ & $0.147 \pm 0.004$ & $26 \pm 5$ & $22 \pm 2$ & $122 \pm 13$ \\
\hline B7 & 7.76 & -141 & 41 & 50 & 2.23 & $15.1 \pm 0.1$ & $31.3 \pm 0.3$ & $349 \pm 2$ & $7.9 \pm 1.4$ & $0.36 \pm 0.12$ & $5.3 \pm 0.1$ & $40 \pm 3$ & $19 \pm 4$ & $0.121 \pm 0.003$ & $20 \pm 4$ & $24 \pm 2$ & $102 \pm 28$ \\
\hline B8 & 7.54 & -116 & 85 & 45 & 2.12 & $21.2 \pm 0.5$ & $45.9 \pm 0.3$ & $448 \pm 10$ & $6.8 \pm 0.7$ & $0.37 \pm 0.14$ & $6.8 \pm 0.5$ & $52 \pm 4$ & $25 \pm 1$ & $0.725 \pm 0.019$ & $29 \pm 1$ & $26.8 \pm 0.1$ & $120 \pm 18$ \\
\hline B9 & 7.65 & -125 & 54 & 49 & 2.24 & $16.1 \pm 0.7$ & $32.8 \pm 0.2$ & $348 \pm 15$ & $8.6 \pm 0.9$ & $0.34 \pm 0.11$ & $5.27 \pm 0.03$ & $41.5 \pm 0.9$ & $20 \pm 2$ & $0.154 \pm 0.004$ & $21 \pm 3$ & $25.6 \pm 0.5$ & $112 \pm 39$ \\
\hline B12 & 7.50 & -158 & 69 & 57 & 2.98 & $16.7 \pm 0.2$ & $38.4 \pm 0.3$ & $307 \pm 6$ & $5.8 \pm 1.9$ & $0.32 \pm 0.10$ & $6.0 \pm 0.3$ & $43.1 \pm 0.1$ & $22 \pm 4$ & $0.128 \pm 0.003$ & $21.4 \pm 0.8$ & $22 \pm 4$ & $114 \pm 33$ \\
\hline B13 & 7.22 & -175 & 81 & 51 & 2.20 & $18.2 \pm 0.3$ & $33.6 \pm 0.1$ & $384 \pm 3$ & $5.6 \pm 0.7$ & $0.24 \pm 0.08$ & $5.68 \pm 0.03$ & $44.7 \pm 0.6$ & $19 \pm 2$ & $0.085 \pm 0.002$ & $24 \pm 2$ & $16.4 \pm 1.0$ & $121 \pm 35$ \\
\hline VA & 7.22 & -184 & 81 & 42 & 1.82 & $9.9 \pm 0.9$ & $23 \pm 1$ & $267 \pm 21$ & $4.8 \pm 0.2$ & $0.49 \pm 0.08$ & $5.4 \pm 0.5$ & $46 \pm 1$ & $17 \pm 1$ & $0.15 \pm 0.01$ & $16.9 \pm 0.1$ & $46 \pm 2$ & $72 \pm 4$ \\
\hline $\mathrm{VC}$ & 7.12 & -196 & 88 & 44 & 3.17 & $14.2 \pm 1.2$ & $29.7 \pm 0.5$ & $262 \pm 15$ & $7.7 \pm 0.3$ & $0.75 \pm 0.09$ & $7.3 \pm 0.7$ & $77 \pm 6$ & $29 \pm 4$ & $0.25 \pm 0.02$ & $30.5 \pm 0.8$ & $47 \pm 1$ & $121 \pm 6$ \\
\hline $\mathrm{VN}$ & 7.35 & -126 & 59 & 49 & 3.60 & $15.4 \pm 0.9$ & $31.4 \pm 0.3$ & $289 \pm 13$ & $8.9 \pm 0.4$ & $0.68 \pm 0.06$ & $7.8 \pm 0.8$ & $74 \pm 1$ & $30 \pm 1$ & $0.27 \pm 0.01$ & $31.8 \pm 0.3$ & $51 \pm 2$ & $166 \pm 13$ \\
\hline B10 & 7.65 & -199 & 86 & 54 & 3.70 & $19.6 \pm 0.1$ & $35.3 \pm 0.3$ & $303 \pm 3$ & $10 \pm 2$ & $1.07 \pm 0.35$ & $7.5 \pm 0.2$ & $72 \pm 4$ & $35 \pm 5$ & $0.317 \pm 0.008$ & $34 \pm 5$ & $98 \pm 13$ & $239 \pm 22$ \\
\hline B11 & 7.40 & -190 & 94 & 43 & 4.07 & $21.0 \pm 0.4$ & $37.7 \pm 0.3$ & $329 \pm 6$ & $11.9 \pm 0.8$ & $1.35 \pm 0.32$ & $8.2 \pm 0.1$ & $100 \pm 3$ & $44 \pm 1$ & $0.43 \pm 0.01$ & $36 \pm 1$ & $74 \pm 0.7$ & $220 \pm 52$ \\
\hline NGB & & & & & & & & & $5.6 \pm 2.0$ & $0.12 \pm 0.01$ & & $47 \pm 10$ & $11 \pm 2$ & $0.14 \pm 0.03$ & $18 \pm 3$ & $11 \pm 4$ & $80 \pm 28$ \\
\hline
\end{tabular}


Table 2: Mean percentage ( \pm standard deviation) of major and trace elements in sediment extracts using EDTA and ascorbate, ranked in descending order for EDTA. The Pearson correlation coefficient $\left(\mathrm{r}^{2}\right)$ between the elements extracted by EDTA and ascorbate is also reported. Values in bold correspond to significant correlations at the 0.05 level.

\begin{tabular}{|c|c|c|c|}
\hline & $\begin{array}{l}\text { EDTA } \\
(n=15)\end{array}$ & $\begin{array}{c}\text { ASCORBATE } \\
(\mathrm{n}=11)\end{array}$ & $\begin{array}{c}\mathrm{r}^{2} \\
(\mathrm{n}=11)\end{array}$ \\
\hline \multicolumn{4}{|c|}{ MAJOR ELEMENTS } \\
\hline $\mathrm{Ca}$ & $106 \pm 7$ & $2.6 \pm 0.5$ & 0.00 \\
\hline $\mathrm{Mn}$ & $73 \pm 8$ & $6 \pm 3$ & 0.43 \\
\hline $\mathrm{Mg}$ & $29 \pm 7$ & $9 \pm 2$ & 0.52 \\
\hline $\mathrm{P}$ & $24 \pm 4$ & $27 \pm 7$ & 0.68 \\
\hline $\mathrm{S}$ & $15 \pm 6$ & $11 \pm 4$ & 0.90 \\
\hline $\mathrm{Fe}$ & $12 \pm 3$ & $12 \pm 3$ & 0.74 \\
\hline $\mathrm{Al}$ & $0.09 \pm 0.04$ & $0.22 \pm 0.05$ & 0.55 \\
\hline \multicolumn{4}{|c|}{ TRACES ELEMENTS } \\
\hline $\mathrm{Pb}$ & $66 \pm 12$ & $3 \pm 2$ & 0.18 \\
\hline $\mathrm{Cu}$ & $38 \pm 10$ & $<1$ & n.d. \\
\hline $\mathrm{Cd}$ & $32 \pm 13$ & $<1$ & n.d. \\
\hline As & $18 \pm 3$ & $29 \pm 5$ & 0.88 \\
\hline Co & $18 \pm 6$ & $15 \pm 3$ & 0.76 \\
\hline $\mathrm{Zn}$ & $17 \pm 5$ & $25 \pm 6$ & 0.62 \\
\hline $\mathrm{Ni}$ & $11 \pm 4$ & $12 \pm 4$ & 0.98 \\
\hline $\mathrm{Cr}$ & $4 \pm 2$ & $5 \pm 3$ & 0.98 \\
\hline
\end{tabular}

Table 3: Pearson correlation matrix for the concentrations of major and trace elements in Alitta succinea tissues. The shaded lines and columns correspond to elements that have been localized in the tissues of organisms by $\mu$ XRF. Values in bold correspond to significant correlations at the 0.05 level.

\begin{tabular}{|c|c|c|c|c|c|c|c|c|c|c|c|c|c|c|c|c|}
\hline & $\mathrm{Ca}$ & $\mathrm{Mg}$ & $\mathrm{P}$ & $\mathrm{S}$ & $\mathrm{Al}$ & $\mathrm{Fe}$ & $\mathrm{Mn}$ & As & $\mathrm{Cd}$ & Co & $\mathrm{Cr}$ & $\mathrm{Cu}$ & $\mathrm{Hg}$ & $\mathrm{Ni}$ & $\mathrm{Pb}$ & $\mathrm{Zn}$ \\
\hline $\mathrm{Ca}$ & 1 & & & & & & & & & & & & & & & \\
\hline $\mathrm{Mg}$ & 0.41 & 1 & & & & & & & & & & & & & & \\
\hline $\mathrm{P}$ & 0.33 & 0.64 & 1 & & & & & & & & & & & & & \\
\hline S & 0.53 & 0.70 & 0.85 & 1 & & & & & & & & & & & & \\
\hline $\mathrm{Al}$ & 0.74 & 0.22 & 0.23 & 0.39 & 1 & & & & & & & & & & & \\
\hline $\mathrm{Fe}$ & 0.71 & 0.37 & 0.14 & 0.41 & 0.73 & 1 & & & & & & & & & & \\
\hline $\mathrm{Mn}$ & 0.76 & 0.36 & 0.23 & 0.33 & 0.76 & 0.75 & 1 & & & & & & & & & \\
\hline As & 0.39 & 0.72 & 0.79 & 0.91 & 0.24 & 0.30 & 0.16 & 1 & & & & & & & & \\
\hline $\mathrm{Cd}$ & -0.16 & 0.33 & 0.11 & 0.10 & -0.24 & 0.04 & 0.01 & 0.36 & 1 & & & & & & & \\
\hline Co & 0.25 & 0.72 & 0.32 & 0.60 & 0.30 & 0.59 & 0.23 & 0.62 & 0.28 & 1 & & & & & & \\
\hline $\mathrm{Cr}$ & 0.29 & 0.41 & 0.22 & 0.37 & 0.27 & 0.56 & 0.40 & 0.43 & 0.71 & 0.54 & 1 & & & & & \\
\hline $\mathrm{Cu}$ & 0.16 & 0.26 & -0.02 & 0.08 & 0.01 & 0.41 & 0.23 & 0.24 & 0.78 & 0.29 & 0.79 & 1 & & & & \\
\hline $\mathrm{Hg}$ & -0.01 & 0.13 & -0.16 & -0.02 & -0.23 & 0.38 & 0.11 & -0.01 & 0.42 & 0.14 & 0.37 & 0.67 & 1 & & & \\
\hline $\mathrm{Ni}$ & 0.60 & 0.44 & 0.48 & 0.68 & 0.46 & 0.71 & 0.37 & 0.70 & 0.20 & 0.52 & 0.54 & 0.36 & 0.39 & 1 & & \\
\hline $\mathrm{Pb}$ & 0.07 & 0.39 & 0.16 & 0.30 & -0.05 & 0.19 & 0.01 & 0.54 & 0.85 & 0.44 & 0.76 & 0.63 & 0.25 & 0.50 & 1 & \\
\hline $\mathrm{Zn}$ & 0.30 & 0.62 & 0.36 & 0.65 & 0.35 & 0.66 & 0.28 & 0.68 & 0.37 & 0.93 & 0.63 & 0.47 & 0.26 & 0.60 & 0.47 & 1 \\
\hline
\end{tabular}

